\title{
Energy Management in Production: A novel Method to Develop Key Performance Indicators for Improving Energy Efficiency
}

ARTICLE in APPLIED ENERGY · JULY 2015

Impact Factor: 5.26 · DOI: 10.1016/j.apenergy.2015.03.065

DOWNLOADS

93
VIEWS

82

4 AUTHORS:

Gökan May

École Polytechnique Fédérale de Lausanne 18 PUBLICATIONS 14 CITATIONS

SEE PROFILE

Bojan Stahl

Politecnico di Milano

14 PUBLICATIONS 6 CITATIONS

SEE PROFILE
Ilaria Barletta

Chalmers University of Technology

5 PUBLICATIONS 2 CITATIONS

SEE PROFILE

Marco Taisch

Politecnico di Milano

88 PUBLICATIONS 246 CITATIONS

SEE PROFILE 


\title{
Energy Management in Production: A novel
}

\author{
Method to Develop Key Performance
}

\section{Indicators for Improving Energy Efficiency}

\section{(Version: Pre-Publication)}

You can view the official version published online in the below link:

doi:10.1016/j.apenergy.2015.03.065

Gökan May ${ }^{\mathrm{a}^{*}}$, Ilaria Barletta ${ }^{\mathrm{b}}$, Bojan Stahl $^{\mathrm{a}}$, Marco Taisch ${ }^{\mathrm{a}}$

${ }^{\text {a} P o l i t e c n i c o ~ d i ~ M i l a n o ~-~ D e p a r t m e n t ~ o f ~ M a n a g e m e n t, ~ E c o n o m i c s ~ a n d ~ I n d u s t r i a l ~ E n g i n e e r i n g, ~}$

Piazza Leonardo da Vinci 32, 20133 Milan, Italy

${ }^{\mathrm{b}}$ Chalmers University of Technology - Department of Product and Production Development, SE-41296 Gothenburg, Sweden

*Corresponding author.

Dr. Gökan May ${ }^{\mathrm{a}^{*}}$

Politecnico di Milano

Department of Management, Economics and Industrial Engineering

Piazza Leonardo da Vinci 32

20133 Milan

Italy

E-mail address: gokan.may@polimi.it 


\section{Energy Management in Production: A novel}

\section{Method to Develop Key Performance}

\section{Indicators for Improving Energy Efficiency}

Measuring energy efficiency performance of equipments, processes and factories is the first step to effective energy management in production. Thus, enabled energy-related information allows the assessment of the progress of manufacturing companies toward their energy efficiency goals. In that respect, the study addresses this challenge where current industrial approaches lack the means and appropriate performance indicators to compare energy-use profiles of machines and processes, and for the comparison of their energy efficiency performance to that of competitors'. Focusing on this challenge, the main objective of the paper is to present a method which supports manufacturing companies in the development of energy-based performance indicators. For this purpose, we provide a 7-step method to develop production-tailored and energy-related key performance indicators (e-KPIs). These indicators allow the interpretation of cause-effect relationships and therefore support companies in their operative decision-making process. Consequently, the proposed method supports the identification of weaknesses and areas for energy efficiency improvements related to the management of production and operations. The study therefore aims to strengthen the theoretical base necessary to support energy-based decision making in manufacturing industries.

Keywords: Energy Management, Key Performance Indicators, Sustainable Manufacturing, Cleaner Production, Energy Efficiency, KPI Method 


\section{Introduction}

The revolution in industry has come along from pure cost to quality and productivity efficiencies and is in the transition towards environmental performance efficiency (Wang et al., 2014; Garetti and Taisch, 2012; Hon, 2005). Closely related to significant improvements in environmental and economic terms, the energy efficiency topic has become important as a field that concerns businesses worldwide, going beyond traditional energy-intensive industries such as the steel, cement, and chemical industries (Palm and Thollander, 2010; Ang, 2006). Over the last few years, policies and private households have also been stirred up by energy efficiency topics due to emergent media coverage and drivers such as climate change, scarcity of resources and rising energy prices (Xu et al., 2014; Karali et al., 2014; Thollander et al., 2013).

Energy efficiency, in the theme of sustainable corporate behavior, is seen as a lever for global competitiveness in the future (Moreno et al., 2014; Drake and Spinler, 2013; Friedler, 2010). Manufacturing accounts for $37 \%$ of primary energy use worldwide (IEA, 2013), and for $40 \%$ of electricity consumption in Europe (European Environment Agency 2010). Accordingly, policymakers and industry are beginning to prioritize the topic on their agenda (Rudberg et al., 2013), examples include the development of the ISO 50001 Energy Management Standard and the Europe 2020 Strategy that aims at achieving 20 percent reduction in overall energy use by 2020 compared to the 2005 baseline (European Commission, 2010). Consequently, avoiding energy waste through energy-aware and optimized production is of utmost importance to cope with increased global competitiveness and adverse environmental impacts. Improving firms' technological and business processes as well as structures and infrastructures have become crucial in order to adequately address these challenges (Kong et al., 2013; Cagno and Trianni, 2013; Saidur and Mekhilef, 2010). Guided by this paradigm shift, it becomes essential to adopt a continuous improvement process for using energy resources more efficiently.

Energy-related information allows the assessment of optimization and improvement potential of energy efficiency measures. Hence it becomes important to provide knowledge that highlights the overall state of the factory and its performance regarding energy consumption. In this regard, performance indicators serve as a measure to decide whether a system is working as it is designed for and helps define progress towards a pre-set target. This enables better monitoring and control of energy consumption which is of utmost important both for current and future enterprises to improve energy efficiency in production (May et al., 2013a). 
While absolute values and aggregated measures like energy consumption per year or per product or similar measures provide an overview on the status quo, it fails to provide decision-making support, transparency and clear identification of action items. Decisionmakers in production require tailored energy-related Key Performance Indicators (e-KPIs) in order to (i) identify firm-specific energy drivers in their production system, (ii) make the energy behavior profile of the production system transparent, (iii) recognize cause-effectrelationships, (iv) prepare actions for improvement measures, and (v) communicate status quo adequately with other inter- and intra-functional areas. Thus, the main objective of the study is to present a method which supports companies independently from the sector or product to develop firm-tailored energy-related KPIs.

The proposed e-KPI method serves as a successful example on how to transfer scientific and research knowledge into industrial value. First, it serves as a practical guide for companies to identify and integrate their most important e-KPIs in the steering and reporting system. Second, the method is developed based on the current state-of-the-art in the field of energyefficient production engineering by backing each step of the procedure with scientifically valid formulas, diagrams and approaches.

The rest of the paper is structured as follows: The next section provides a theoretical background on energy efficiency in production engineering, then goes on to describe derived gaps and industry needs, and answers how we address these issues. Then, we present the research methodology which incorporates empirical and axiomatic approaches to support validity of results. The following section describes the e-KPI method, while the subsequent sections explain the inclusion in the corporate decision- making process. Finally, we end the paper by highlighting important findings and research limitations, and conclude by providing an outlook for future research. 


\section{Literature Review}

Performance indicators play a significant role in evaluating the efficiency and effectiveness of manufacturing systems for a target performance area (e.g. cost, sustainability, energy efficiency). In the last decade, efforts in the academia and industry shifted towards achieving energy efficiency in manufacturing. In this context, many scholars discussed energy efficiency measures, standards, labelling regulations, metrics and performance measurement on national and policy level [e.g. (Shi, 2014); (Xu et al., 2014); (Soundararajan et al., 2014); (Song et al., 2014); (Trianni et al., 2014); (Honma and Hu, 2014); (Wang et al., 2012); (Thollander et al., 2005)]. On a more disaggregated level, studies focused on modelling energy consumption [e.g. (Dietmair et al., 2011) and (Dietmair and Verl, 2009)], and a varied set of approaches have been developed for improving energy efficiency performances in production from machine tool to plant (i.e. an array of machine tools and processes) level. For instance, Hu et al. (2012), He et al. (2012) and Devoldere et al. (2007) focused on improving energy efficiency on machine tool level.

There is a similar situation for manufacturing at production system and factory level where several heterogeneous solutions have been offered regarding energy consumption and efficiency [e.g. (Zhu et al. 2014); (Kong et al., 2013); (Tucker and Ward, 2012); (Sun et al., 2012); (Kissock and Eger, 2008)]. Other recent studies proposed techniques and tools for energy management [e.g. (Dobes, 2013), (Giacone and Manco, 2012), (Giacone et al., 2008) and (Mouzon et al., 2007)]. Monitoring and control approaches as a part of energy management were addressed in several articles [e.g. Cruycke, 2008)], aiming at the development of appropriate methods for improving energy performances in manufacturing.

The US Environmental Protection Agency introduced the ENERGY STAR industry program, promoting indicators as an effective lever to measure energy-based performances (US EPA, 2003). Later, Boyd et al. (2008) described the importance of these indicators for benchmarking plant energy consumption. Feng and Joung (2011) proposed a sustainable manufacturing measurement infrastructure and Tanaka (2008) explored different ways to measure energy efficiency performance. Additionally, Aguirre et al. (2011) proposed metrics called 'energy-production signatures' for diagnosis of energy inefficiencies and benchmarking of energy-related performances of manufacturing plants. Later, Zhou et al. (2012) developed an approach for monitoring energy efficiency trends over time in a country and for comparing the economy-wide energy efficiency performance among countries. 
Based on an analysis of relevant literature and industry, Bunse et al. (2011) highlighted the importance of energy-related production performance indicators as a key need of the manufacturing industry for identifying inefficiencies within a plant's energy consumption, particularly placing emphasis on the improvement potential at the machine tool level. In this context, Vikhorev et al. (2013) provided a decision support framework for the monitoring and management of energy consumption in a factory, focusing on the energy used by productive resources. However, that particular paper by Vikhorev et al. (2013) focused solely on the energy aspects and thus lacked a consideration of synergies and trade-offs with other production performance indicators. In another recent study, Aramcharoen and Mativenga (2014) identified critical energy states for machining components to support energy consumption analysis of machines and work pieces.

The review of the pertinent literature reveals that both academia and industry still lack approaches and tools to better understand the energy consumption behavior and inefficiencies of machine tools, particularly with a focus on synergies and trade-offs with other production management decisions (e.g. quality, maintenance, production planning, etc.).

This study is built upon the research gaps derived in May et al. (2013a) which carried out a comprehensive review of the literature on energy-related key performance indicators and May et al. (2013b) which analyzed the industrial needs toward energy efficient manufacturing. Thus, based on insights from the aforementioned two previous studies of the authors, Table 1 highlights the research gaps and industrial needs addressed in this study. The table also explains how these gaps are addressed in the research work, thus presenting progress beyond the published literature on KPIs for energy efficiency. 
1 Table 1. The research gaps and industrial needs addressed in the study

\begin{tabular}{|c|c|c|c|}
\hline $\begin{array}{l}\text { Gap description } \\
\text { (adapted from May } \\
\text { et al. 2013a) }\end{array}$ & $\begin{array}{c}\text { Industry Need } \\
\text { (adapted from May et al. } \\
\text { 2013b) }\end{array}$ & $\begin{array}{l}\text { Degree of } \\
\text { GAP } \\
\text { Satisfaction }\end{array}$ & How the study addresses the gap \\
\hline $\begin{array}{l}\qquad \underline{G A P 1} \\
\text { Only few of the state- } \\
\text { of-the-art energy- } \\
\text { related indicators are } \\
\text { suitable for energy } \\
\text { management } \\
\text { applications within a } \\
\text { manufacturing plant }\end{array}$ & $\begin{array}{c}\text { More direct focus for } \\
\text { supporting energy } \\
\text { management at plant level: } \\
\text { Energy-related KPIs at } \\
\text { machine, process and plant } \\
\text { level }\end{array}$ & $\begin{array}{c}\text { Decisive } \\
\text { Contribution }\end{array}$ & $\begin{array}{l}\text { Development of energy-related KPIs at } \\
\text { machine level. Application of the method is } \\
\text { currently dedicated to machine tools and } \\
\text { machining centers. The method can be } \\
\text { extended to more aggregate levels }\end{array}$ \\
\hline $\begin{array}{l}\qquad \underline{G A P 2} \\
\text { Benchmarking of } \\
\text { energy efficiency } \\
\text { between } \\
\text { manufacturing plants } \\
\text { is difficult and not } \\
\text { always applicable }\end{array}$ & $\begin{array}{l}\text { Benchmarking-oriented plant } \\
\text { level KPIs which can compare } \\
\text { energy efficiency of different } \\
\text { plants and processes that are } \\
\text { similar in terms of features of } \\
\text { production }\end{array}$ & $\begin{array}{c}\bigcirc \\
\text { Marginal } \\
\text { Contribution }\end{array}$ & $\begin{array}{l}\text { The analysis of the cause-effect relationship } \\
\text { between energy consumption and } \\
\text { manufacturing system shows the existence of } \\
\text { a large number of variables that affect energy } \\
\text { consumption. The proposed e-KPIs offer } \\
\text { ample possibilities for use in benchmarking } \\
\text { applications considering the different } \\
\text { variables of energy consumption }\end{array}$ \\
\hline \multirow{2}{*}{$\begin{array}{c}\underline{G A P 3} \\
\text { Indicators do not } \\
\text { report any } \\
\text { information about } \\
\text { how energy is used in } \\
\text { a manufacturing plant } \\
\text { Technological } \\
\text { monitoring limits } \\
\text { exist }\end{array}$} & $\begin{array}{l}\text { Energy-related KPIs which } \\
\text { identify inefficiencies at plant } \\
\text { level }\end{array}$ & $\begin{array}{l}\text { Decisive } \\
\text { Contribution }\end{array}$ & $\begin{array}{l}\text { The purpose, with which the energy-related } \\
\text { KPIs are developed, is to provide an analysis } \\
\text { tool that can be easily used by management to } \\
\text { identify inefficiencies and areas for } \\
\text { improvement with the aim of continuous } \\
\text { improvement }\end{array}$ \\
\hline & $\begin{array}{l}\text { Using real time, high granular } \\
\text { information of energy } \\
\text { consumption through smart } \\
\text { sensors }\end{array}$ & $\begin{array}{c}\text { Decisive } \\
\text { Contribution }\end{array}$ & $\begin{array}{l}\text { The developed method is aimed at utilizing } \\
\text { the full potential of energy measurement and } \\
\text { monitoring technologies }\end{array}$ \\
\hline $\begin{array}{l}\qquad \underline{G A P 4} \\
\text { Few guidelines are } \\
\text { available on selection } \\
\text { and use of energy- } \\
\text { related KPIs }\end{array}$ & $\begin{array}{l}\text { Support on design, } \\
\text { definition and use of energy- } \\
\text { related KPIs }\end{array}$ & $\begin{array}{c}\text { Modest } \\
\text { Contribution }\end{array}$ & $\begin{array}{l}\text { The cross-view method is detailed step-by- } \\
\text { step that could help manufacturing companies } \\
\text { develop and use firm-tailored e-KPIs }\end{array}$ \\
\hline \multirow{2}{*}{$\begin{array}{l}\qquad \underline{\text { GAP 5 }} \\
\text { Energy management } \\
\text { decision support tools } \\
\text { through KPIs are not } \\
\text { well developed }\end{array}$} & $\begin{array}{l}\text { Energy-related continuous } \\
\text { improvement performance }\end{array}$ & $\begin{array}{c}\text { Modest } \\
\text { Contribution }\end{array}$ & $\begin{array}{l}\text { The e-KPI management phase demonstrates } \\
\text { how the method and system of indicators are } \\
\text { designed for the energy management in order } \\
\text { to effectively use the information potential } \\
\text { offered by the indicators }\end{array}$ \\
\hline & $\begin{array}{l}\text { Methods for understanding } \\
\text { cause-effect relationships } \\
\text { between production } \\
\text { management and energy- } \\
\text { related performance }\end{array}$ & Decisive & $\begin{array}{l}\text { The cause-effect relationships represent the } \\
\text { core phase of the method, and develop a panel } \\
\text { of variables that affect energy consumption. } \\
\text { The related clustering is represented by the } \\
\text { Ishikawa diagram, in which these variables } \\
\text { are associated with different energy states of } \\
\text { the machine tool through the cause-effect } \\
\text { linkages }\end{array}$ \\
\hline
\end{tabular}




\section{Research Methodology}

The development of methodologies and approaches which are specifically designed to support decision-making processes can suffer from a mutual relationship of academic and practical stringency: (i) the approach is scientifically rigid, but difficult to apply in practice (the practice gap) or (ii) the approach is applicable in practice but scientifically not underpinned (the research gap). To overcome these two major methodological drawbacks, we employed a pragmatist research view with the inclusion of both empirical and axiomatic measures. The axiomatic approach is based on the traditional conceptual modelling (Meredith, 1993), and incorporates methods that have the potential to support e-KPI definition and implementation. The empirical part consists of semi-structured interviews to better understand the problems related to industry and to receive a continuous feedback about the research progress. Through the employment of conceptual modelling in combination with empirical semi-structured interviews, we have installed a valid mechanism to cope with the research and practice gap and support the validity of the developed method.

Semi-structured interviews with industry have been carried out to gather information besides those obtainable from literature and to support development of the e-KPI method. The interview was composed of 14 wide-ranging questions in an attempt to cover the major energy areas of interest for the discussion, and aims at defining:

- initial formulation of manufacturing and energy states;

- cause and effect links between these manufacturing and energy states;

- projected future developments for the application of the e-KPI method.

The case companies and interviewees are described in Table 2:

Table 2. Description of companies and interviewees

\begin{tabular}{|c|l|l|l|}
\hline Company & Description & Interviewees & Company Size \\
\hline \multirow{2}{*}{ Company } & One of the global leading & $\begin{array}{l}\text { Production Manager of } \\
\text { Engine \& Machinery }\end{array}$ & $\begin{array}{l}\text { Employees: more } \\
\text { than 3500 } \\
\text { A }\end{array}$ \\
machinery, engines and & Mechanical Operations & Revenue: app. $€ 1.2$ \\
& agricultural machinery & Bergamo, Italy & billion (in 2013) \\
\hline
\end{tabular}




\begin{tabular}{|c|c|c|c|}
\hline $\begin{array}{c}\text { Company } \\
\text { B }\end{array}$ & $\begin{array}{l}\text { German multinational } \\
\text { engineering \& electronics } \\
\text { conglomerate company }\end{array}$ & $\begin{array}{l}\text { 1. Sustainable Production } \\
\text { Engineer } \\
\text { 2. Corporate Technology } \\
\text { Researcher } \\
\text { Munich Headquarters, } \\
\text { Germany }\end{array}$ & $\begin{array}{l}\text { Employees: } \\
\text { app. } 400000 \text { across } \\
190 \text { countries } \\
\text { Revenue: app. €75 } \\
\text { billion (in 2013) }\end{array}$ \\
\hline $\begin{array}{c}\text { Company } \\
\text { C }\end{array}$ & $\begin{array}{l}\text { Multinational } \\
\text { semiconductor chip maker } \\
\text { corporation which develops } \\
\text { advanced integrated digital } \\
\text { technology products and } \\
\text { primarily integrated circuits }\end{array}$ & $\begin{array}{l}\text { 1. Energy Manager } \\
\text { 2. Production Engineer } \\
\text { Production Facility in } \\
\text { Leixlip, Ireland }\end{array}$ & $\begin{array}{l}\text { Employees: app. } \\
100000 \text { world-wide } \\
\text { (in 2013) } \\
\text { Revenue: app. €50 } \\
\text { billion (in 2014) }\end{array}$ \\
\hline $\begin{array}{c}\text { Company } \\
\text { D }\end{array}$ & $\begin{array}{l}\text { Global supplier of industrial } \\
\text { automation systems and } \\
\text { services mainly for the } \\
\text { automotive manufacturing } \\
\text { sector }\end{array}$ & $\begin{array}{l}\text { 1. Head of Advanced } \\
\text { Engineering } \\
\text { 2. Plant Manager } \\
\text { Production Facility in } \\
\text { Torino, Italy }\end{array}$ & $\begin{array}{l}\text { Employees: app. } \\
14500 \text { (in 2013) } \\
\text { Revenue: app. €1.7 } \\
\text { billion (in 2013) }\end{array}$ \\
\hline $\begin{array}{c}\text { Company } \\
\text { E }\end{array}$ & $\begin{array}{l}\text { Italian Machine Tool } \\
\text { Industry }\end{array}$ & Director General & $\begin{array}{l}\text { Association with } \\
\text { over } 200 \text { associate } \\
\text { member companies }\end{array}$ \\
\hline
\end{tabular}

The interview is divided into four parts, each of which contains a set of open-ended questions:

The first part - Business context - aims at ascertaining the existence of an effective alignment between the information obtained from the selected company and the information necessary. Through a series of questions, a check is performed on the compatibility of the company's profile with the profile of companies for which the method can potentially be applied. 
Moreover, by virtue of this introductory check, the quality and accuracy of the information obtained from the interview is ensured.

Second part - Industrial Scenario - proposes a series of questions to investigate the state of the art regarding energy-related performance indicators in production and to acquire information beyond those available in the literature.

The third part - Design Method - aims at evaluating the design of the method considered in terms of scope, comprehensiveness of the elements analyzed, consistency and continuity between the logical steps and stages of the method.

The fourth part - Implementation of the Method - concerns the possible structure and drivers for actual use of the e-KPI method. This last part focused on the strengths and weaknesses (both technological and managerial) and expected benefits of the implementation of the proposed method.

Combining the empirical and axiomatic approach, the proposed e-KPI method is presented in the next section. 


\section{4. e-KPI Method}

Current efficiency or effectiveness indicators of equipment are time-based (e.g. OEE). However, to fully assess the energy-related efficiency or effectiveness of an equipment, the time-based view alone is not sufficient (May et al. 2013a). It is necessary to create energyrelated key performance indicators (e-KPI). Furthermore, current energy performance indicators are calculated through aggregate measures of energy consumption (e.g. $\mathrm{kWh} /$ month or $\mathrm{kWh} / \mathrm{part}$ ). This approach lacks a thorough consideration of cause-effect relationships between manufacturing states (i.e. causes of energy inefficiencies of the productive resource), machine configurations and energy consumption. Hence, detailed performance analysis and the identification of real energy consumer is complicated.

In this section, we develop a method to define and use energy-related KPIs which allows the interpretation of cause-effect relationships and therefore support companies in the operative decision-making process. The method is designed for the work-unit (i.e. machine) level of a manufacturing facility which is selected based on its major contribution to energy consumption and energy efficiency improvement potential as emphasized by Gutowski et al. (2006), Huang (2008) and May et al. (2013a).

The proposed e-KPI method connects manufacturing states (power consumption variables, measured in $[\mathrm{t}]$ ) to energy states (power requirement [W]) through cause-effect relationships. These consumptions are represented in energy diagrams, enabling definition of the energyrelated KPIs. e-KPI refers to an indicator made up of energy consumption data and production data gathered from shop floor in discrete or continuous time, and highlights efficiency levels for different operations of energy-consuming productive resources. Following this, energy diagrams are built by using a time-based approach for developing performance indicators, and resulting e-KPIs represent energy alter-ego of time-based efficiency indicators.

Finally, e-KPI management mechanism, from a continuous improvement point of view, aims at recording developed indicators in a template to identify variables of energy consumption which mostly have shown energy inefficiencies through analysis of e-KPI values. Next, an action plan is created to reduce the entity of these variables for reducing both the amount of time spent and energy consumed with respect to any specific power requirement under scrutiny. 
The e-KPI method comprises the following steps as shown in Figure 1:

- Definition of the reference production system;

- Identification of different power requirements of the productive resource;

- Analysis of manufacturing states as causes of energy inefficiencies of the productive resource;

- Linking drivers (time view) with the appropriate power requirements (energy view);

- Building a hierarchical framework of machines' energy consumption;

- Development of e-KPIs;

- e-KPI design and management.

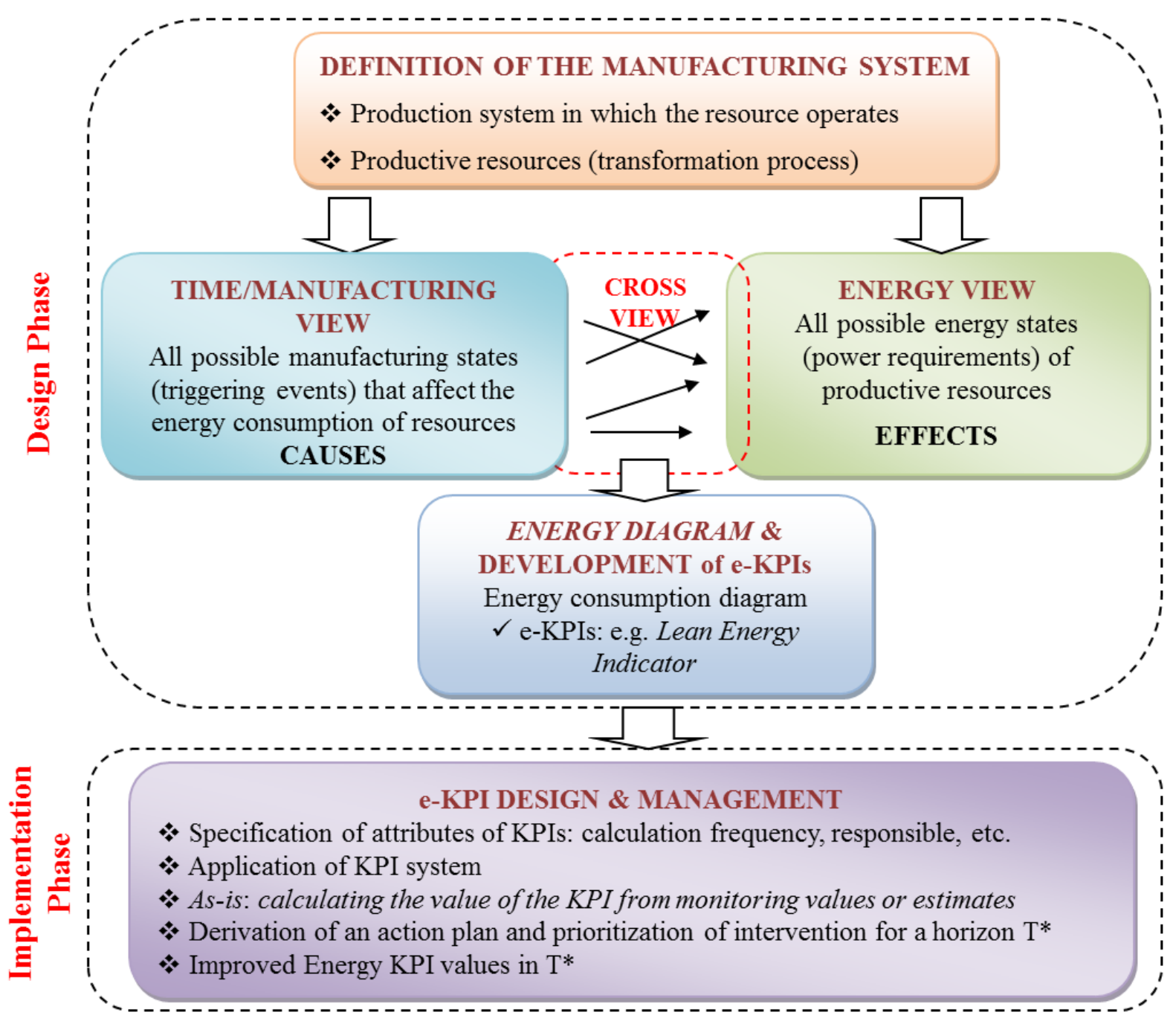

Figure 1. Steps of the e-KPI method 


\subsection{Step 1 - Definition of the Reference Production System}

The first step in the KPI development method is to define the resources. In this step, a reference production system is selected for applying the e-KPI method. Defining the reference productive system means specifying:

1. Discrete manufacturing industry which we refer to (e.g. electrical, mechanical, automotive, robotics, etc.)

2. Transformation process or production resource within the plant (e.g. milling, molding, painting, etc.)

3. Specifications of the manufacturing system based on the following dimensions:

a. Typology: unit production; batch production; continuous production

b. Market dimension: single job orders; repetitive job orders; production based on forecasts (MTS)

c. Layout: job shop; cell; assembly line: fixed, cell, line

d. Automation Degree: automatic transfer line; numerical control; flexible manufacturing system; flexible manufacturing cells; flexible manufacturing line

\subsection{Step 2 - Identification of different power requirements of the productive resource}

The energy view of the resource is obtained by analyzing its electrical power requirement [W] for which time length (and thus the energy consumption associated with it) can be potentially affected by decisions taken for the management of the resource or the production system as a whole. These power requirements in the method represent the energy states. The improvement of energy performance of the resource through monitoring and analysis is enabled exclusively by managerial levers (e.g. by an improved production scheduling).

The term energy view refers to power requirements of the resource selected in step 1 for differing energy states. At this stage, it is therefore necessary to identify all possible energy states in which the resource can be during the operation and which can be changed by management levers.

The energy states considered in this study have been derived from different sources such as the Association of Italian Manufacturers of Machine Tools, Robots \& Automation (UCIMU) and literature (Mouzon et al., 2007; Calvanese et al., 2013). The energy states considered are thus identified as off, ramp-down, stand-by, maintenance, idle, set up, ramp-up and processing as described in the table 3 below. 
Table 3. Energy States

\begin{tabular}{|c|c|c|}
\hline Energy State & Description & Power \\
\hline Off & Machine tool is off: no power is required & Constant \\
\hline Ramp-down & Energy is consumed for machine shut-down & Variable \\
\hline Stand-by & $\begin{array}{l}\text { Machine has most of the components switched-off, and } \\
\text { machine is not ready to process parts. Only some components } \\
\text { require power in order to reduce activation time }\end{array}$ & Constant \\
\hline Maintenance & $\begin{array}{l}\text { Machine is being repaired with some specific actions that } \\
\text { require power }\end{array}$ & Constant \\
\hline Idle & $\begin{array}{l}\text { Machine is not processing any parts, and this is the base load of } \\
\text { machine to keep components ready to process parts }\end{array}$ & Constant \\
\hline Set-up & Energy is consumed to change the tool & Variable \\
\hline Ramp-up & Energy is consumed to start machine & Variable \\
\hline Processing & Machine is processing parts & Variable \\
\hline
\end{tabular}

\subsection{Step 3 - Analysis of manufacturing states as causes of energy inefficiencies of the productive resource}

The time view of the resource involves determining all temporal or manufacturing states which can be observed during operation. Manufacturing states define a condition of inefficiency, i.e. the loss or waste that impacts on energy consumption of the resource itself. For this reason, manufacturing states are defined as affecting variables of energy consumption. The variables of energy consumption are special states of the system expressed as time intervals, where variables of energy consumption is a synonym for manufacturing states to emphasize the impact on energy consumption.

For a comprehensive definition of the variables of energy consumption, it is essential to have a good knowledge and understanding of the functioning of the resource within the production system. Since the literature itself provides valid overview of factors and drivers that affect energy consumption and overall environmental performance, the Ishikawa diagram is used in this discussion to represent the cause and effect relationships.

Definition of the energy affecting states of the production resource according to the productivity-based time view is inspired by Morvay \& Gvozdenac (2008). The identified manufacturing states are listed in Table 4, including their description and corresponding intervention mechanisms that show how to reduce the impact of that manufacturing state: 
1 Table 4. Manufacturing states and intervention mechanisms

\begin{tabular}{|c|c|c|c|}
\hline Manufacturing State & Description & Magnitude recorded (in T) & Intervention mechanisms \\
\hline $\begin{array}{l}\text { Blocking \& Starvation }(B \& S) \text { for } \\
\text { Production Scheduling }\end{array}$ & $\begin{array}{l}\text { Idling due to management reasons, relevant } \\
\text { to production planning (Operation Loading } \\
\text { and sequencing). }\end{array}$ & $\begin{array}{l}\mathrm{T}_{\mathrm{bsps}} \\
\text { Time in blocking \& starvation } \\
\text { for production scheduling }\end{array}$ & $\begin{array}{l}\text { - quality of the loading and dispatching rules } \\
\bullet \text { size of the buffer system } \\
\bullet \text { throughput } \\
\text { - cycle times of the pieces of the product mix }\end{array}$ \\
\hline $\begin{array}{c}\text { Waiting Tool } \\
\text { (missing tool in tool buffer) }\end{array}$ & $\begin{array}{c}\text { Idling caused by the expectation of a } \\
\text { missing tool in the buffer of the machine } \\
\text { tool }\end{array}$ & $\begin{array}{c}\mathrm{T}_{\mathrm{wttm}} \\
\text { Time in waiting tool for tool } \\
\text { management } \\
\text { (usually estimated) }\end{array}$ & $\begin{array}{l}\text { - Sizing tool buffer on the machine (primary } \\
\text { storage) and warehouse } \\
\text { - handling system for tools (automatic or } \\
\text { manual), tool management }\end{array}$ \\
\hline Daily Starting & $\begin{array}{l}\text { If the company works on } 1 \text { or } 2 \text { shifts per } \\
\text { day, the machines are restarted daily. If the } \\
\text { company works in } 3 \text { shifts with } 5 \text { working } \\
\text { days, it is rebooted after the weekend }\end{array}$ & $\begin{array}{l}\mathrm{T}_{\text {rampup }} * \mathrm{~N}_{\mathrm{st}} \\
\text { Ramp-up time for number of } \\
\text { starts }\end{array}$ & Shifts of the plant \\
\hline Starting post Holidays & Start of the machine after the holidays & $\begin{array}{c}\mathrm{Ns}_{\mathrm{ph}} * \mathrm{~T}_{\text {rampup }} \\
\text { Number of post-holiday starts } \\
\text { times ramp-up time }\end{array}$ & Calendar \\
\hline Set-up & Tool change & $\begin{array}{l}\mathrm{T}_{\mathrm{su}} \\
\text { Set-up time: it is the tool } \\
\text { change time chip-to-chip } \\
\text { (ISO10701-9) }\end{array}$ & $\begin{array}{l}\text { - systems for the optimization of the number of } \\
\text { tool changes }\end{array}$ \\
\hline Missing Orders (MO) & $\begin{array}{c}\text { The inactivity of the machine for expected } \\
\text { Missing Orders }\end{array}$ & $\begin{array}{c}\mathrm{T}_{\mathrm{mo}} \\
\text { Time of missing orders }\end{array}$ & $\begin{array}{l}\text { - customer demand and order frequency } \\
\text { - Master Production Schedule (MPS) }\end{array}$ \\
\hline Missing Materials (MM) & $\begin{array}{c}\text { The inactivity of the machine for expected } \\
\text { Missing Materials }\end{array}$ & $\begin{array}{c}\mathrm{T}_{\mathrm{mm}} \\
\text { Time of missing materials }\end{array}$ & $\begin{array}{l}\text { - reliability of the upstream provider (internal or } \\
\text { external) } \\
\text { - procedures and criteria of choice of supplier } \\
\text { by the Purchasing }\end{array}$ \\
\hline Test \& Sampling & $\begin{array}{l}\text { The machine processes for testing and } \\
\text { sampling }\end{array}$ & $\begin{array}{c}\mathrm{T}_{\mathrm{ts}} \\
\text { Time for test \& sampling. } \\
\text { Total processing time of test } \\
\text { pieces and samples }\end{array}$ & - requested by the Planning \\
\hline $\begin{array}{c}\text { Machine's } \\
\text { Microstoppages }\end{array}$ & Microstoppages & $\begin{array}{c}\mathrm{T}_{\text {micro }} \\
\text { Total time lost for } \\
\text { microstoppages of the } \\
\text { machine }\end{array}$ & $\begin{array}{l}\text { - age and wear of machine } \\
\text { - quality of preventive maintenance plans } \\
\bullet \text { multiple factors }\end{array}$ \\
\hline
\end{tabular}




\begin{tabular}{|c|c|c|c|}
\hline Manufacturing State & Description & Magnitude recorded (in T) & Intervention mechanisms \\
\hline $\begin{array}{c}\text { Corrective Maintenance: Total/Partial } \\
\text { Failures in Down }\end{array}$ & $\begin{array}{l}\text { Time in corrective maintenance in which } \\
\text { the machine remains in Down state }\end{array}$ & $\begin{array}{c}\mathrm{T}_{\mathrm{down}} \\
\text { Composed by: Delay time } \\
\text { (management) + diagnosis } \\
\text { time + delay time (logistics) } \\
\text { Nspf*Trampup } \\
\text { Number starting post failure }\end{array}$ & $\begin{array}{c}\bullet \text { quality of preventive maintenance plans } \\
\bullet \text { manpower training: } \\
\text { timeliness of the operators in recognizing and } \\
\text { reporting faults } \\
\bullet \text { maintenance training: } \\
\text { timeliness of the maintenance team to arrive on } \\
\text { the scene }\end{array}$ \\
\hline $\begin{array}{l}\text { Corrective Maintenance: Total/Partial } \\
\text { Failures in Maintenance }\end{array}$ & $\begin{array}{c}\text { Time in Corrective maintenance during } \\
\text { which the machine remains in state of } \\
\text { Maintenance }\end{array}$ & $\begin{array}{l}\mathrm{T}_{\text {maint }} \\
\text { Composed by: Time for } \\
\text { technical repair }+ \text { Time to } \\
\text { return in service }\end{array}$ & $\begin{array}{l}\bullet \text { entity of the fault } \\
\text { - training maintenance: prompt repair of the } \\
\text { maintenance team }\end{array}$ \\
\hline Planned Maintenance & $\begin{array}{l}\text { Time in planned maintenance during which } \\
\text { the machine remains in state of } \\
\text { Maintenance }\end{array}$ & $\begin{array}{c}\text { TTR }_{\mathrm{p}} \\
\text { Repair time for preventive } \\
\text { interventions }\end{array}$ & - maintenance training: for rapid adjustments \\
\hline $\begin{array}{l}\text { Waiting Tool for tool breakdown or } \\
\text { regeneration }\end{array}$ & $\begin{array}{c}\text { The tool breakage involves waiting for the } \\
\text { machine, as well as its regeneration, in case } \\
\text { there is not another copy of the tool on the } \\
\text { machine }\end{array}$ & $\begin{array}{c}\mathrm{T}_{\mathrm{wtbr}} \\
\text { Time in waiting tool for } \\
\text { breakdown or regeneration }\end{array}$ & $\begin{array}{c}\text { - tool wear } \\
\text { - regeneration frequency of the tool } \\
\text { - sizing tool buffer on the machine (primary } \\
\text { storage) and warehouse } \\
\text { - handling system for tools (automatic or } \\
\text { manual), tool management } \\
\text { - depth of cut, work performed on special } \\
\text { materials }\end{array}$ \\
\hline $\begin{array}{l}\text { Blocking \& Starvation due to failures of } \\
\text { manufacturing system }\end{array}$ & $\begin{array}{l}\text { If the operating stations are not sufficiently } \\
\text { decoupled, faults in other elements of the } \\
\text { system (e.g. machines upstream and } \\
\text { downstream) may involve expectations of } \\
\text { the machine. }\end{array}$ & $\begin{array}{c}\mathrm{T}_{\mathrm{bssf}} \\
\text { blocking \& starvation time for } \\
\text { system's failures }\end{array}$ & $\begin{array}{l}\text { - age and wear of machines and components of } \\
\text { the production system } \\
\bullet \text { size of the buffer system } \\
\text { - intervention mechanisms related to corrective } \\
\text { maintenance }\end{array}$ \\
\hline Rejected in start up & Waste during the start up & $\begin{array}{c}\mathrm{Q}_{\mathrm{rs}} \\
\text { Pieces discarded in start-up }\end{array}$ & $\begin{array}{l}\bullet \text { age and wear of machine } \\
\bullet \text { tolerances required in the finished parts }\end{array}$ \\
\hline Rejected/ Reworked in normal production & $\begin{array}{l}\text { Waste and recycling systems during normal } \\
\text { production. }\end{array}$ & $\begin{array}{c}\mathrm{Q}_{\text {rej, }} \mathrm{Q}_{\mathrm{r}} \\
\begin{array}{c}\text { Amount of waste / recycling } \\
\text { during production }\end{array}\end{array}$ & $\begin{array}{l}\text { - age and wear of machine } \\
\bullet \text { quality Management }\end{array}$ \\
\hline $\begin{array}{c}\text { Workers' Stoppages (during production } \\
\text { or in shift change) }\end{array}$ & $\begin{array}{l}\text { Workers' stoppages which involve } \\
\text { expectations for the machine }\end{array}$ & $\begin{array}{c}\mathrm{T}_{\mathrm{sw}} \\
\text { Time of workers' stoppages }\end{array}$ & - labor productivity \\
\hline Strikes & $\begin{array}{l}\text { Strikes and trade union causes during } \\
\text { business hours }\end{array}$ & $\begin{array}{c}\mathrm{T}_{\text {strike }} \\
\text { Time for strikes }\end{array}$ & $\begin{array}{l}\text { - socio-economic problems } \\
\text { - salary, occupational safety }\end{array}$ \\
\hline
\end{tabular}


The variables affecting energy consumption of a machine tool are identified and represented in five clusters (i.e. production management, quality, manpower, maintenance, and external causes). Each cluster relates to a univocal responsibility and the Ishikawa diagram is used during this step to identify the relationships between different manufacturing states and energy consumption. The manufacturing system variables affecting energy consumption are thus identified as illustrated in the diagram below:

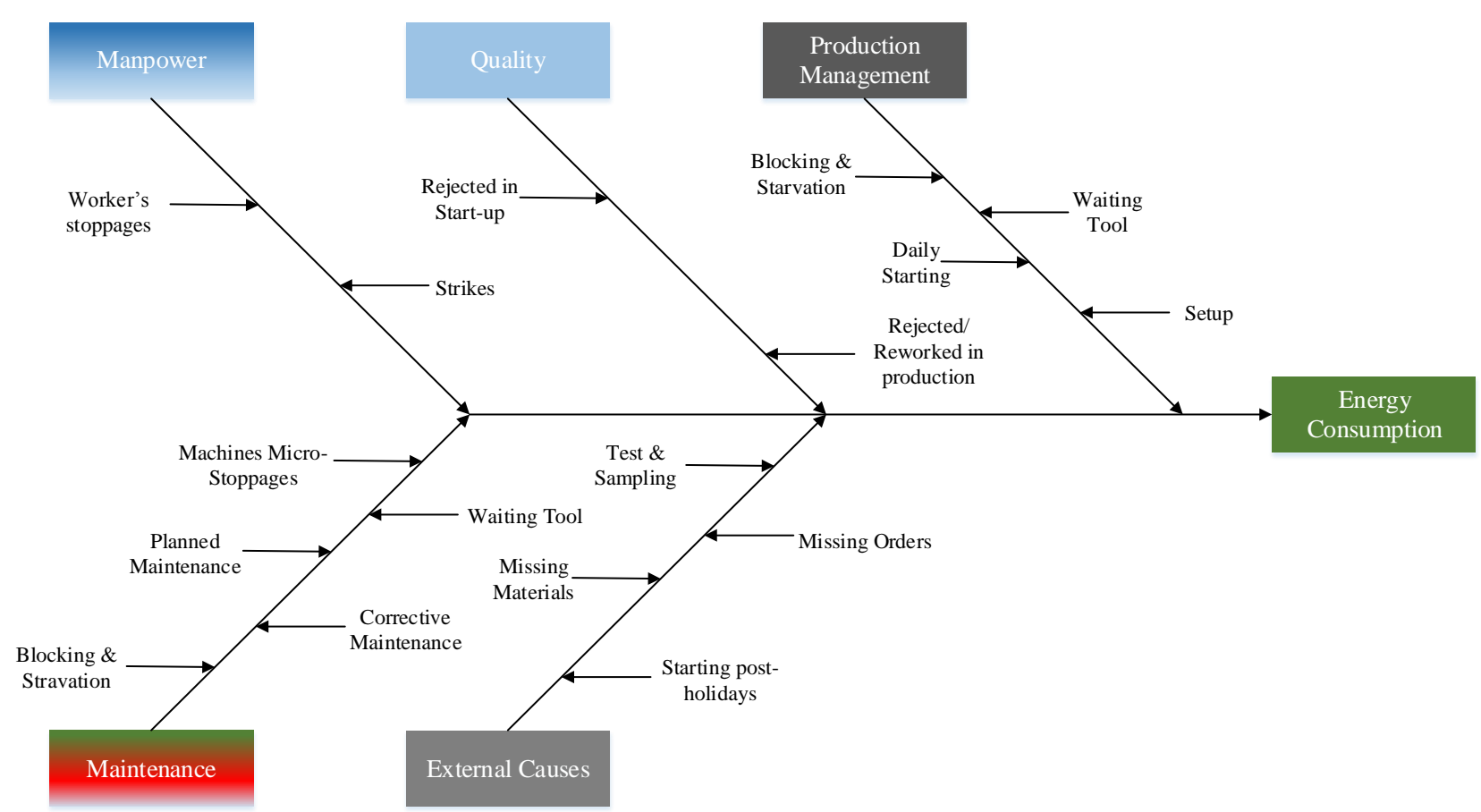

Figure 2. Relationships between manufacturing states and energy consumption

\subsection{Step 4 - Linking manufacturing states with energy states}

One of the most critical point of the e-KPI method is the linking process between manufacturing/time view (causes) and energy view (effects), because it depends strongly on:

- Resource/process selected;

- Dimensions of previously defined manufacturing system, particularly the layout and automation degree;

- The understanding of system behavior (what variables impact on energy consumption);

- The hypothesis done in order to simplify the application of the method;

- The availability of data.

After identifying the manufacturing states and the energy states for the productive resource, we proceed to establish the links between them. Each link represents the specific impact that a manufacturing state has on a given energy state. 
The links between identified manufacturing states and energy states have been established by utilizing prior knowledge and by conducting semi-structured interviews with the industrial partners. This knowledge serves to develop energy-related KPIs.

Figure 3 illustrates the cross view diagram. The links in the diagram were first developed independently and then refined upon discussions with the case companies. Further information for designing these cross links is provided below:

1. Each manufacturing status box is marked by the colour relative to the cluster it belongs to (see figure 3);

2 . Since the e-KPIs are indicators of energy consumption resulting from the cross-linking, the Off state is not considered in the analysis since corresponding energy consumption for this state is equal to zero;

3. Since the maximum power of the ramp down is very low (before decreasing toward zero power), it is not considered in the cross-linking;

4. To increase the readability of the diagram through a lower number of status box, blocking $\&$ starvation was put in a group together with the state of waiting tool, both for the cluster of production management and for that of maintenance, since their links with the energy states are identical. These groups appear as 'idling production management' and 'idling maintenance' in the cross-link diagram;

5. Strikes have been neglected and are ideally embedded in the workers' stoppages;

6. Missing orders and missing materials have been grouped together in the same box as their corresponding energy states are identical. 


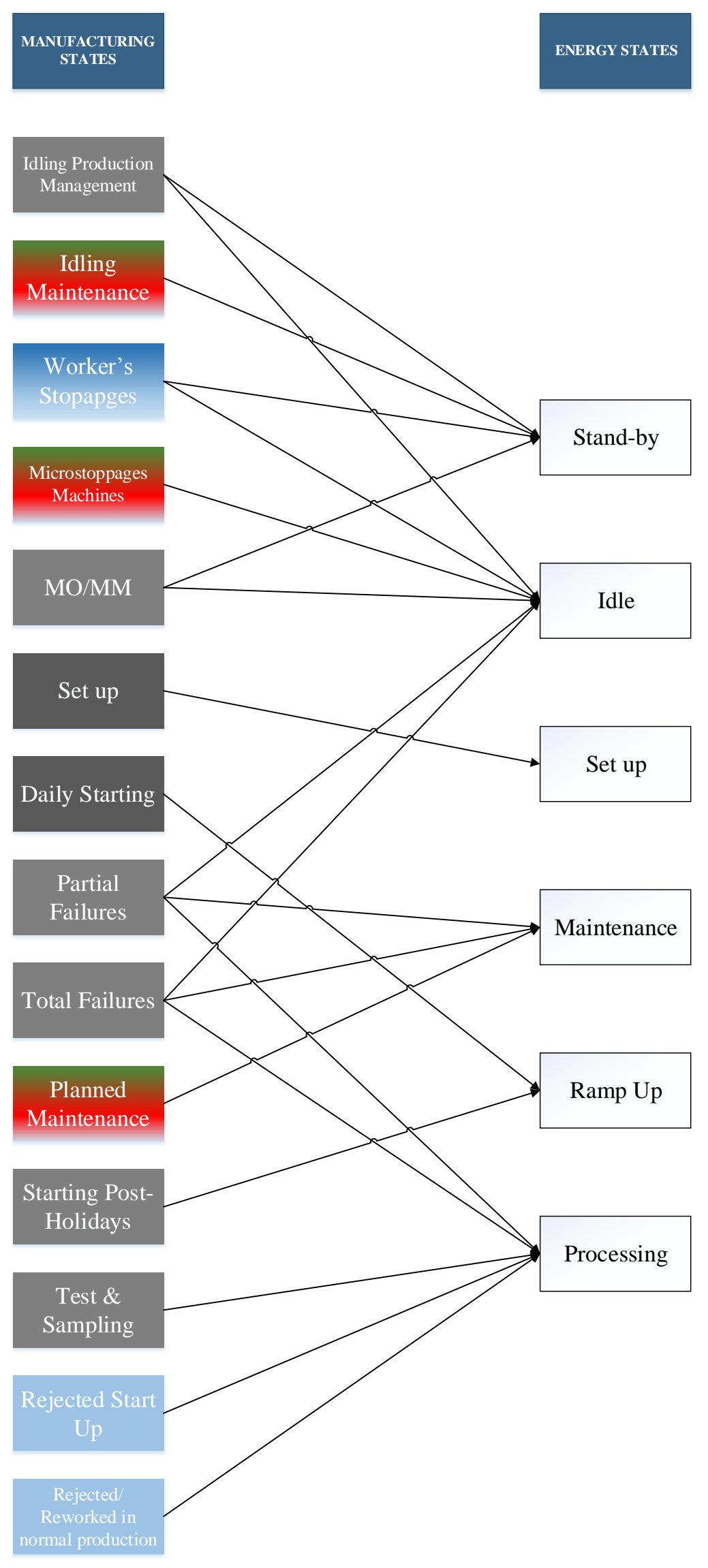

Figure 3. Cross-links between manufacturing states and energy states 


\subsection{Step 5 - Building a hierarchical framework of machine's energy consumption}

The energy diagram illustrates energy consumption associated with each manufacturing state. It is an aggregation of the time intervals [T] that the machine has spent in a certain energy state [W]. The total energy consumption of a machine in a certain time period $\mathrm{T}$ is the integral of power function up to the time T.

There are high power requirements with lower occurrence in time (e.g. processing), as well as lower power requirements with greater occurrence in time (e.g. idle). The existence of these circumstances is clearly dependent on what happens to the machine and to production system within which it operates.

Energy diagrams also provide the percentage contribution of different power requirements on total energy consumption. In the literature, approaches of this type have been used to evaluate, for instance, a high consumption rate of the machine in idle state compared to that of processing (Gutowski et al., 2006). Other examples include development of indicators with an approach to calculate the contribution of each energy state on the total energy consumption in order to assess the appropriateness of different production scenarios in terms of energy saving (Cannata et al., 2010). The development of the KPIs following this approach provides decision support for energy management if the goal is to design a decision support tool solely based on KPIs. However, without determining cross-links, it would not be possible to contextualize the reasons for a higher idle consumption of a process compared to the previous period. It is therefore necessary to design an appropriate Energy Diagram to support the development process of these e-KPIs.

The e-KPIs are designed to represent the value-adding electrical energy consumption input for the selected productive resource that is used for the production of saleable output. Moreover, these KPIs show the amount of energy wasted by operations, procedures and management, related with operating the production system. In this way, the e-KPIs clearly highlight and help prioritize the potential areas for improving energy efficiency.

The proposed framework and steps have been considered in deriving energy-related KPIs. The identified e-KPIs can be used in order to diagnose energy consumption trends, address responsibilities of energy consumption and monitor effectiveness of action plans through time. This facilitates the continuous improvement of energy-related performances in a manufacturing plant. Therefore, we need to represent energy consumption in a framework that allows us to build KPIs quantifying different impacts of variables. A Russian doll representation is suitable for this purpose. The structure of the histogram depends on the links between time view and energy view. Small 
rectangles are variables and the arrows link the related energy consumption to each of the variables (these links depend on specific case). Figure 4 below shows the Energy Diagram developed for this purpose.

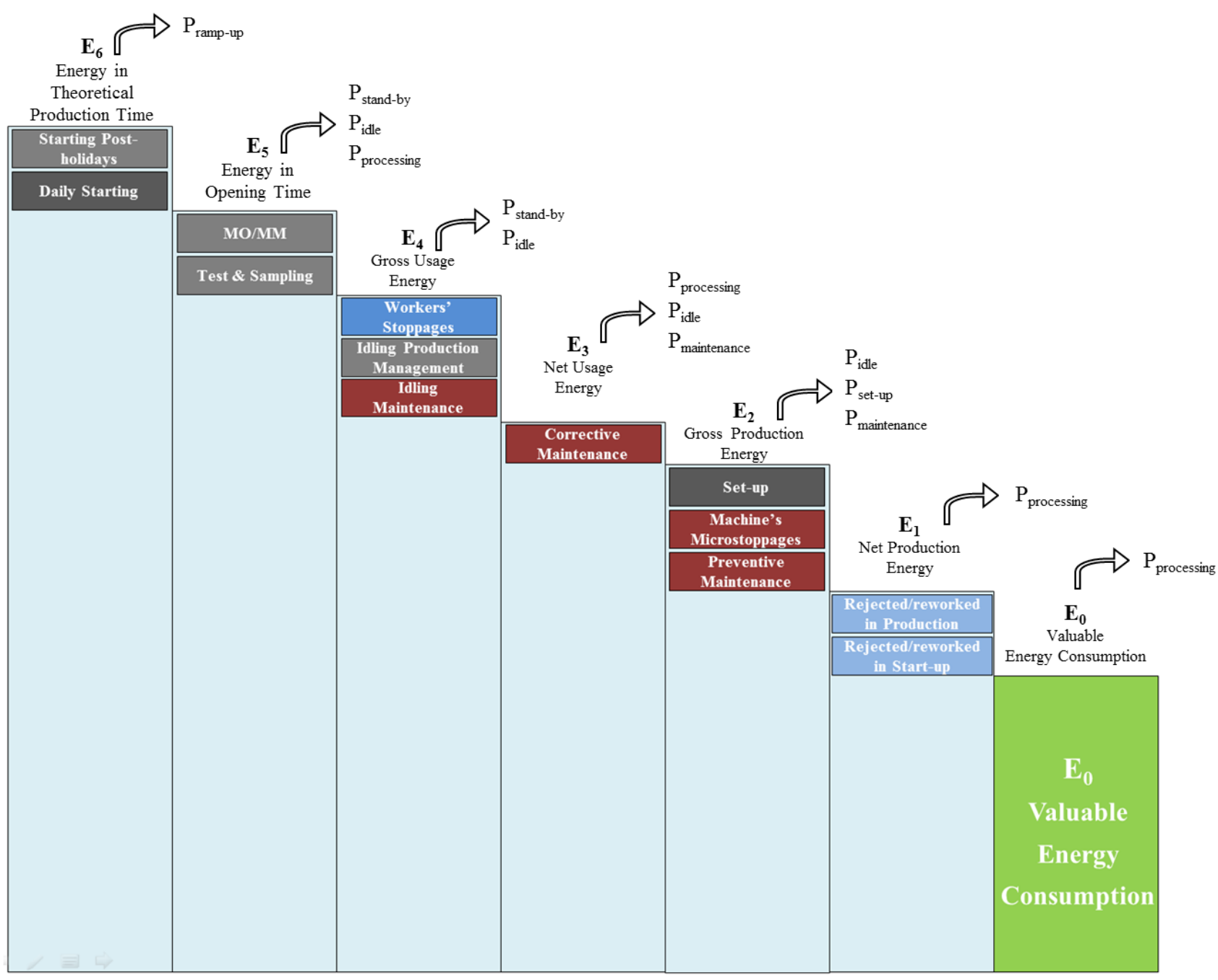

Figure 4. Energy Diagram

The first pillar from the left represents the total energy consumed in the theoretical production time $\mathrm{T}$ (i.e. calendar time). We proceed by climbing down the energy consumption attributed to the different states through the manufacturing cross-links, down to the valuable energy consumption, i.e. the useful energy associated with the production of saleable parts without defects.

Each block of the diagram is evaluated in terms of energy from the power requirement resulting from the cross-linking process (through the arrows in the figure). The amount of energy consumption scaled in the diagram is to be considered qualitative.

This alter-ego involves the introduction of a change in the way in which the inefficiencies are considered in the traditional time-based view. Two types of losses (e.g. lack of orders and set up) of equal temporal entity (e.g. both 2 hours a day) do not have the same weight in terms of energy efficiency (which should have a perspective of time-based efficiency), since they are associated 
with a weight which is the relative power requirement. For this reason, it is interesting to analyze the inefficiencies from an energy perspective. The effort here is focused on reducing the contribution of the manufacturing states with the highest impact on the overall energy consumption of the productive resource.

Using energy diagram, we build KPIs that emphasize contribution of different factors such as the Utilization, Availability, Saturation and Yield normally used in time/productivity view (e.g. Grando and Turco, 2005) for the calculation of productivity index. These KPIs also emphasize contribution of studied clusters (i.e. production management, quality, manpower, maintenance, and external causes) so that we can address a particular energy inefficiency to its corresponding univocal actor within the manufacturing system. This is a powerful tool for diagnosis of energy inefficiencies, and we can also build aggregate KPIs and break them down to emphasize possible trade-offs.

\subsection{Step 6 - Development of e-KPIs}

We now proceed to formulization of the e-KPIs. We introduce the symbols used in the formulas for calculating indicators in Appendix A.

The Lean Energy Indicator shows how efficient the equipment is in terms of energy consumption. It represents the ratio of energy consumed for producing saleable products to overall energy consumption of the machine. This indicator is thus derived by dividing the value-added energy to the energy consumption detected in the theoretical production time:

$$
\text { Lean Energy Indicator }=\frac{\text { Valuable Energy Consumption }}{\text { Overall Energy Consumption }}=\frac{E 0}{E 6}
$$

or:

$$
\text { Lean Energy Indicator }=\frac{\sum_{i=1}^{n}\left(P_{\text {processing } i} \times Q_{\text {good } i} \times T_{\text {processing } i}\right)}{\text { Energy Consumed in Theoretical Production time }}
$$

The goal here is not to minimize the energy consumption in absolute terms since there is a demand of production which must be satisfied, but to use energy more efficiently for production of one saleable output. For this reason, we aim at achieving Lean Energy Indicator closer to 1.

In this way, we can understand the causes of an increase in overall energy consumption (E6) compared to that required for producing a single good product (E0). A good way to do this is to breakdown this indicator to multiple factors.

Analyzing the energy diagram from the right, we understand how easy it is to generate a second indicator: the indicator $E_{\text {quality }}$ represents the energy that is wasted due to quality problems.

$$
E_{\text {quality }}=\frac{\text { Valuable Energy Connsumption }}{\text { Net Production Energy }}=\frac{E 0}{E 1}
$$

or: 


$$
E_{\text {quality }}=\frac{\sum_{i=1}^{n}\left(P_{\text {processing } i} \times Q_{\text {good } i} \times T_{\text {processing } i}\right)}{\sum_{i=1}^{n}\left(P_{\text {processing } i} \times T_{\text {processing } i}\right) \times\left(Q_{\text {good } i}+Q_{\text {rs } i}+Q_{r i}+2 Q_{\text {rew } i}\right)}
$$

From (4), we see that part of the product mix that consumes more energy, for which $P_{\text {processing } i} \times$ $T_{\text {processing } i}$ value is higher than other pieces, impact more on the total value, and consequently the effort must be directed to reduce the waste corresponding to production of this type of pieces. For simplicity, we consider the presence of a process which has a binary condition output: good piece or discarded piece. $Q_{\text {tot } i}$ here represents the total amount produced for each piece "i":

$$
Q_{\text {tot } i}=Q_{\text {good } i}+Q_{\text {rsi }}+Q_{r i}
$$

Place $Q_{\text {tot } i}=Q_{\text {good } i}+Q_{r s i}+Q_{r i}$ to (4), then:

$$
E 1=\sum_{i=1}^{n}\left(P_{\text {processing } i} \times T_{\text {processing } i} \times Q_{\text {tot } i}\right)
$$

(with the possibility of having excluded the amount reworked), we build the indicator Energy in Saturation $\left(E_{\text {sat }}\right)$ :

$$
\text { Energy in Saturation }\left(E_{\text {sat }}\right)=\frac{\text { Net production Energy }}{\text { Gross Production Energy }}=\frac{E 1}{E 2}
$$

The unsaturation of the resource, as assessed by the corresponding time-based performance indicator, is due to a series of events that slow down production of the resource (in the time available), such as minor stops and setups. For this reason, micro stops, adjustments, and setup are considered in the calculation of energy consumption.

$$
E_{\text {sat }}=\frac{E 1}{E 1+P_{\text {idle }}\left(T_{\text {micro }}\right)+P_{\text {maint }}(T T R p)+\sum_{i=1}^{n} Q_{\text {tot } i} N c t_{i}\left(P_{\text {setup }} \times T_{\text {su }}\right)}
$$

If the value of the indicator approaches to the value "1", the saturation of the equipment is higher and the energy loss relative to it is lower (i.e. the impact of the energy losses of micro stops, set-up and adjustment).

One can easily imagine how the process of developing energy-related KPIs through the Energy Diagram has recursive nature until getting to the final condition of obtaining an e-KPI that has the total energy consumption in the period (E6) as its denominator.

The indicator Energy in Availability $E_{\text {avail. }}$ depends on the maintenance time required. It is shown in (8) and (9):

$$
\text { Energy in Availability }\left(E_{\text {avail. }}\right)=\frac{\text { Gross Production Energy }}{\text { Net Usage Energy }}=\frac{E 2}{E 3}
$$

Place $E 2=E 1+P_{\text {idle }}\left(T_{\text {micro }}\right)+P_{\text {maint }}(T T R p)+\sum_{i=1}^{n} Q_{\text {tot } i} N c t_{i} T_{\text {su }}$ from (7) to (8), then:

$$
\left(E_{\text {avail. }}\right)=\frac{E 2}{E 2+P_{\text {maint }} T_{\text {maint }}+P_{\text {ramp up }} T_{\text {ramp up }} N_{\text {spf }}+P_{\text {idle }} T_{\text {down }}}
$$


This indicates a good example to emphasize the difference of the time-based view and the energybased view: if the restart time of a machine tool for failure is negligible in terms of its inclusion in the indicator of availability, then this does not apply from an energy point of view, given that the power ramp-up is a power requirement less than that required for example by machining, but definitely not negligible. The effort will therefore be addressed to avoid this kind of total failures, and in general, to avoid the occurrence of all manufacturing states for which the power consumption is higher.

We analyze now the indicator $E_{\text {usage }}$, which assesses the impact of causes at the level of the overall system and not strictly at machine level .

$$
E_{\text {usage }}=\frac{\text { Net Usage Energy }}{\text { Energy in operating time }}=\frac{E 3}{E 5}
$$

Place E3 $=E 2+P_{\text {maint }} T_{\text {maint }}+P_{\text {ramp up }} T_{\text {ramp up }} N_{\text {spf }}+P_{\text {idle }} T_{\text {down }}$ from (9) to (10), we have:

$$
E_{\text {usage }}=\frac{E 3}{E 3+P_{\text {idle }}\left(T_{b s p s}+T_{w t t m}+T_{b s s f}+T_{w t b r}+T_{w s}\right)+P_{\text {processing }} T_{t s}+P_{\text {standby }}\left(T_{m o}+T_{m m}\right)}
$$

The disuse of a resource is determined by causes related to the management of the production system (blocking \& starvation), tool management, and processing of samples and test pieces due to problems such as the lack of external orders and lack of materials.

Finally, it is possible to calculate an indicator $E_{\text {opening }}$, assessing the impact of the post-holiday or post-shift start-ups of the machine. Consistent with the Energy Diagram in Figure 4, it is calculated relative to the energy in time T. $E_{\text {opening }}$ is shown in (12) and (13):

$$
E_{\text {opening }}=\frac{\text { Energy Consumption in Opening Time }}{\text { Energy Consumption in Theoretical Production Time }}=\frac{E 5}{E 6}
$$

Place From (11):

$$
\begin{gathered}
E 5=E 3+P_{\text {idle }}\left(T_{\text {bsps }}+T_{w t t m}+T_{\text {bssf }}+T_{w t b r}+T_{w s}\right)+P_{\text {processing }} T_{t s}+P_{\text {standby }}(M O+M M) \text {, then: } \\
E_{\text {opening }}=\frac{E 5}{E 5+P_{\text {rampup }} T_{\text {rampup }}\left(N_{s p h}+N_{s t}\right)} \text { (13) }
\end{gathered}
$$

Finally, we can derive Lean Energy Indicator through the contribution of individual indicators presented such as $E_{\text {openinig, }} E_{\text {usage }}, E_{\text {availl }}, E_{\text {sat }}, E_{\text {quality }}$ from (13):

$$
\text { Lean Energy Indicator }=E_{\text {opening }} \times E_{\text {usage }} \times E_{\text {avail }} \times E_{\text {sat }} \times E_{\text {quality }}=\frac{E 0}{E 6}
$$

In conclusion, the Lean Energy Indicator highlights how much value-added energy (processing) is used for the production of saleable output, in relation to the total energy consumption. The latter can be analyzed and interpreted through a decomposition of Lean Energy Indicator in factors such as $E_{\text {opening }}, E_{\text {usage }}, E_{\text {avail }}, E_{\text {sat }}, E_{\text {quality }}$. 
The representation that provides (14) is an excellent support to the interpretation of the causes behind which the power consumption incurred for the production of a manufacturing output is not value-added (i.e. causes of energy inefficiency).

The value for each of the developed e-KPIs range from 0 to1. Different uses of these e-KPIs are studied in detail in the below section 4.7, i.e. Step 7 - e-KPI design and management.

\subsection{Step 7 - e-KPI Design and Management}

The second macro-step of the method is the implementation phase as highlighted in Figure 5. Once designed, the KPIs must be managed. The boxes below illustrate the meanings of design and management of the e-KPIs, which are explained in detail in sections 4.7.1 and 4.7.2 respectively.
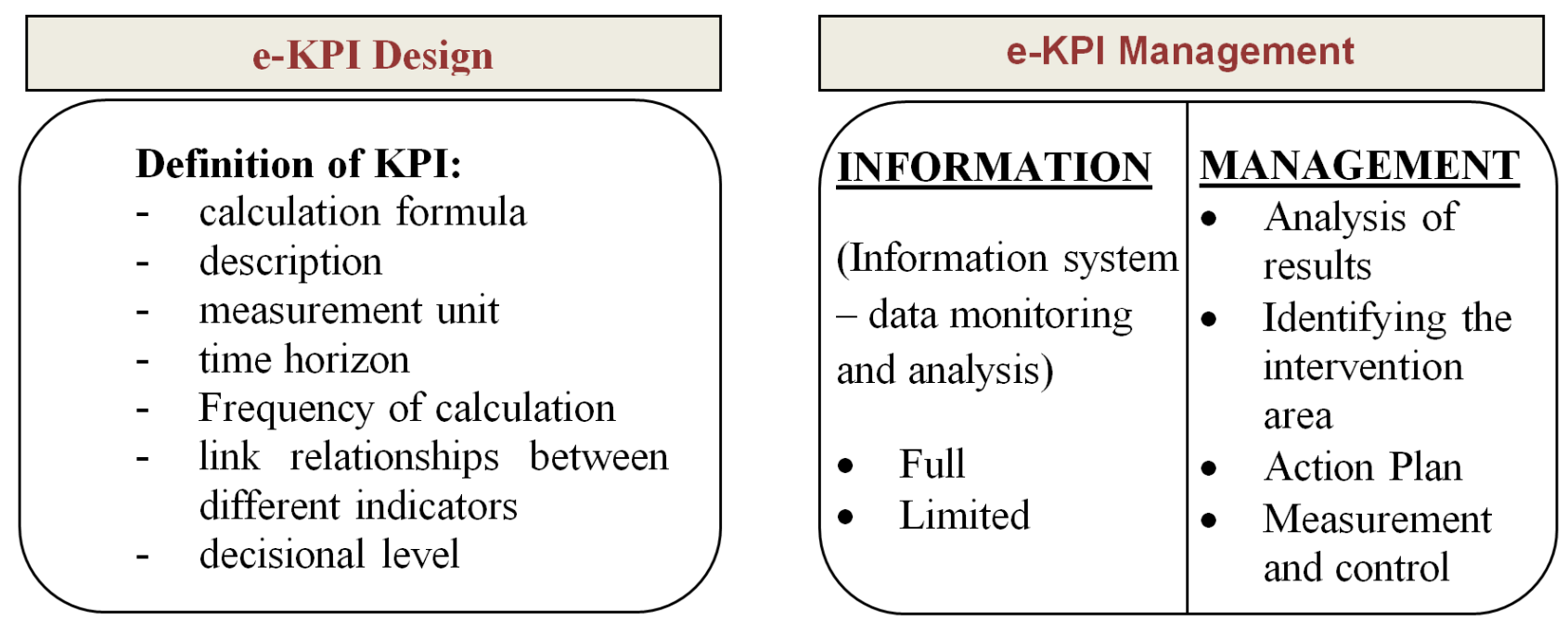

Figure 5. Design and management of e-KPIs

\subsection{1. e-KPI Design}

To provide a detailed guideline for the use of the designed e-KPIs, it is necessary to keep it in a record sheet, filling the attributes listed in the left-hand column of Figure 5. A valid reference time horizon for calculation of these indicators is the minimum interval of months which contain a large set of energy consumption variables, on which it makes sense to perform an analysis. Regarding the frequency of the calculation, it clearly depends on the quality of the monitoring system, as well as the management and control requirements.

\subsection{2. e-KPI Management}

Once the KPI system is designed, it must be managed for the purpose for which it has been created or to enable the continuous improvement of energy-related performances. This section discusses how the implementation of an e-KPI system as well as the implementation of any KPI system focused on continuous improvement can be studied from two perspectives: (i) Implementation from an information infrastructure point of view; (ii) Implementation of the KPI system from the management point of view (i.e. of utmost interest for the case in question). 
From the information point of view, the implementation of the method can happen in two ways, i.e. full implementation and limited implementation.

a. Full implementation

The case of full implementation occurs if an advanced energy monitoring system exists in the company, and this situation leads to an optimum result that the method is able to make in terms of decision making support. The sensors at the machine, line or plant level allow a high quality and accuracy of the data that may be provided in real-time or discrete, depending on the level of automation in the whole factory. In this type of situation, the final energy consumption would automatically be built and disassembled through the e-KPI, knowing the basic information on the behavior of the manufacturing system (e.g. failure times, set up times, missing orders, etc.).

b. Limited implementation

Since in the case of certain non-automated or poorly automated situations, calculations of the values of KPIs can be performed manually through spreadsheets, it is only possible to apply the method through energy consumption data (in the period established by the timescale) obtained from a measurement campaign or reasonable estimates. In case of limited implementation, measurement frequency would be lower than in the case of the full implementation, and the information obtained from e-KPI is represented by poor quality of the data.

The inclusion of limited implementation and its comparison with the full implementation within the e-KPI Management is carried out solely by virtue of a possible argument about the time horizon for implementation of method. To apply the method in the short term, a limited implementation could be considered while in the medium and long term an application of the method in its optimal mode can be suggested based on the industry needs and trends outlined previously.

From the management point of view, the implementation is the management of the KPI system in relation to the purpose for which it is created, or to enable the continuous improvement of the energy-based performances. In this sense, it is important to establish a method for performance analysis and prioritization of actions.

After the monitoring and measurement of the performance through the KPIs, the step traditionally performed in this context includes:

- the analysis of the values supplied by the KPIs;

- their correct interpretation and communication to interested parties;

- identification of potential areas for improvement;

- $\quad$ setting objectives and actions for improvement;

- checking the results through a new measurement and analysis of the e-KPI values after a certain time horizon. 


\section{Decision Support Mechanism}

It is now necessary to explain how the structured system design and use of e-KPIs could serve as a diagnosis and decision support tool for energy managers and in general for management involved in the energy efficiency programs.

Since the design criteria of the e-KPIs is precisely to enable the decision making, the first analysis of the values provided by the KPI as well as the identification of potential areas for improvement, is inherent in the way in which the e-KPIs are designed. The e-KPIs are therefore easy to read in terms of the identification of the satisfaction degree of energy-related performances and to identify areas for intervention and responsible actors. The farthest the e-KPI value is from the ideal value of 1 , the greater the need for intervention within the area defined by the cluster associated with the indicator. In reference to the developed e-KPIs, for example, a low value of $E_{\text {avail }}$ compared to other indicators $E_{\text {opening }}, E_{\text {usage }}, E_{\text {sat }}, E_{\text {quality }}$ which form the Lean Energy Indicator suggests a need for intervention within the engineering of maintenance and/or in the maintenance function, and similarly a low value of $E_{\text {quality }}$ suggests a strong impact of quality problems on energy inefficiencies.

By considering $E_{\text {avail }}$ as an example, the energy consumption at a low value of the defendants are represented by high values of the sum $P_{\text {maint }} T_{\text {maint }}+P_{\text {ramp up }} T_{\text {ramp up }} N_{\text {spf }}+P_{\text {idle }} T_{\text {down }}$, i.e. the denominator of the indicator [see (7)].

To understand the extent to which it is possible to act on the e-KPI identified as responsible for the deterioration of the performance, a contextualization should be made for the determinants of the identified KPI, ideally analyzed utilizing the energy consumption matrix illustrated in Figure 6.

The matrix includes two dimensions :

1. The horizontal dimension represents the magnitude of the individual energy consumption [i.e. the magnitude of the single power requirement (energy in each instant of time, e.g. $P_{\text {ramp up }}$ ]

2. The vertical dimension represents the time in which the single power requirement has been observed in the monitoring time $\mathrm{T}$ (in reference to the example, it corresponds to $T_{\text {ramp up }} N_{\text {spf }}$ ) 


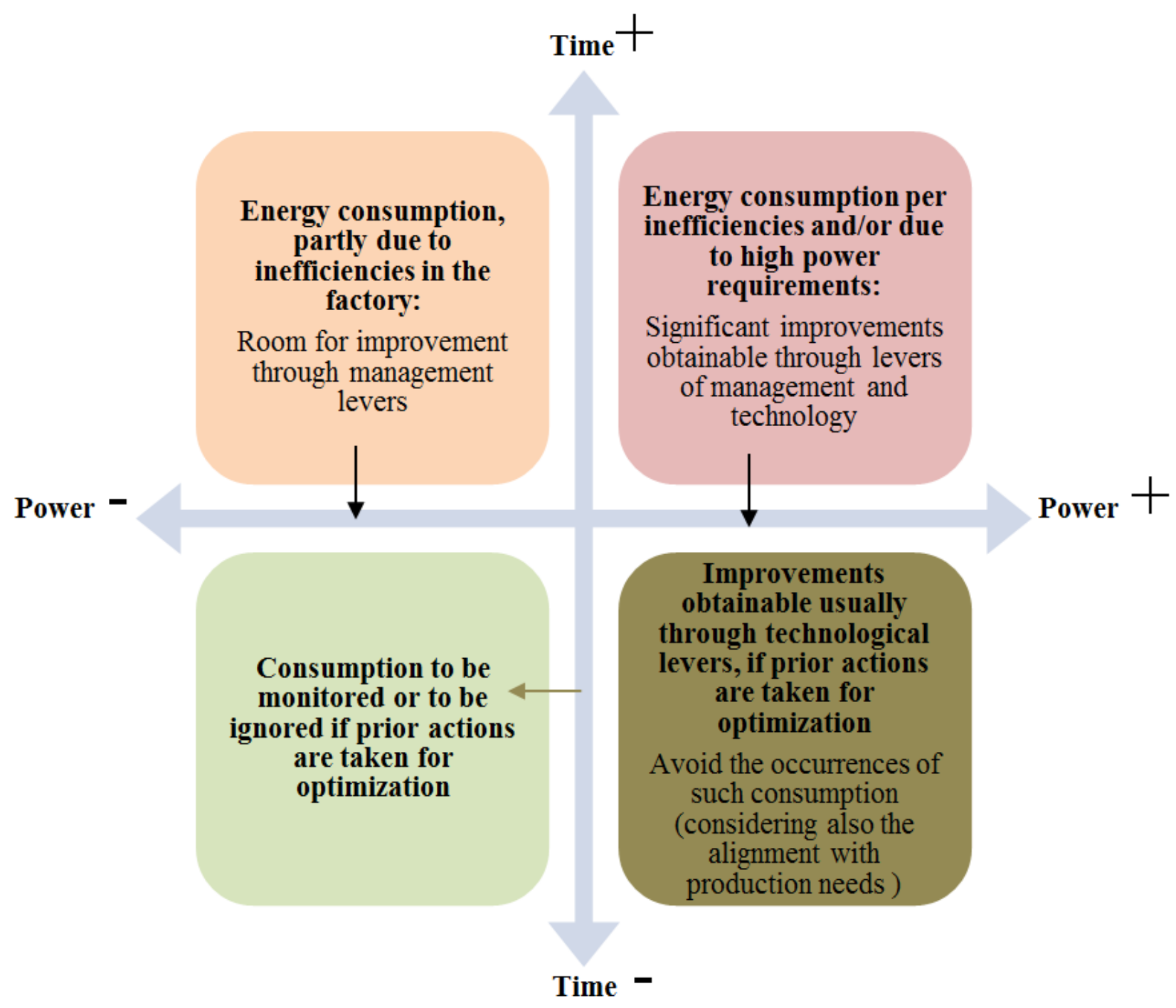

Figure 6. Energy consumption matrix for decision support

The nature of the energy consumption denotes the lever through which to reduce the entity. Figure 6 shows the directions (through the arrows) for improvement in correspondence with each area. Since the focus is on energy management, improvement levers are oriented to reduce energy consumption where possible. Technological improvements (e.g. buy machines which spend less energy per unit of time) are considered out of scope for the discussion in this section.

One area of focus is that of the first quadrant: longer times and high power. With regard to the fourth quadrant, besides the fact that longer times may also be due to factors that do not directly involve inefficiencies, it is still an area within which it is worth investigating to see if longer times actually occurred due to a certain state of inefficiency (e.g. if repair times and $T_{\text {maint }}$ are higher than the standard). This information can be found in mainstream systems such as MES, SCADA and ERP. In the case of inefficiency, high energy consumption of this type can easily be reduced through management levers, the cost of which can be discussed with other actors of the plant. 
In the example under investigation, it is important to know where consumption that makes up the sum $P_{\text {maint }} T_{\text {maint }}+P_{\text {ramp up }} T_{\text {ramp up }} N_{\text {spf }}+P_{\text {idle }} T_{\text {down }}$ is going to be placed within the energy consumption matrix. The positioning depends on the exact values that each time variable and power variable correspond to. Nonetheless, it is good to seize any opportunity to reduce energy consumption through management levers, reasonably applicable in the example under consideration, since the high consumption may be due to high fault-repair time during which the machine is in the maintenance state, or due to high number of reboots and time spent during postfailures of the machines in a fault state previous to the repair during which the machine stays in idle state.

Therefore, the macro problem is identified through the e-KPI at a lower value, contextualized energy consumption is attributed to it, and intervention possibility and areas are evaluated accordingly. Next step is to determine how to intervene in order to properly secure objectives and action plan for achieving identified improvements. Table 5 shows an example to this point.

Table 5. Intervention mechanisms related to the example of reduction in the value of $\boldsymbol{E}_{\text {avail }}$

\begin{tabular}{|c|c|c|}
\hline \multicolumn{1}{|c|}{$\begin{array}{c}\text { Manufacturing } \\
\text { State }\end{array}$} & Intervention mechanisms \\
$\begin{array}{c}\text { Corrective Maintenance: } \\
\text { Total/Partial Failures in } \\
\text { Down }\end{array}$ & $\begin{array}{c}T_{\text {ramp up }} N_{\text {spf }} \\
T_{\text {down }}\end{array}$ & $\begin{array}{c}\text { Intimess of the operators in recognizing and reporting faults } \\
\text { maintenance training: }\end{array}$ \\
\hline $\begin{array}{c}\text { Corrective Maintenance: } \\
\text { Total/Partial Failures in } \\
\text { Maintenance }\end{array}$ & $T_{\text {maint }}$ & timeliness of the maintenance team to arrive on the scene \\
\hline
\end{tabular}

Discharging the opportunity to act on specific energy consumption and on how to act, goals can be set at management level to control the length of time of manufacturing states. Based on the nature of the intervention mechanisms, the negative contribution of the indicator $E_{\text {avail }}$ could be through an action plan structured as follows:

- a reconsideration of the frequency intervals in preventive maintenance by engineering;

- the adoption of a maintenance training program for practitioners, for the early detection of faults;

- the adoption of a training program for the maintenance team.

The objectives are broken down into tasks and the action plan is released. On the basis of the extent of the program provided, it establishes a timeframe within which it is expected that the indicator $E_{\text {avail }}$ provides better performance, closer to the value of 1 in the current period. 
Naturally, due to the way in which the e-KPIs are designed through the Energy Diagram, the value of each KPI depends exclusively on the set of variables which forms the indicator, and is not dependent in any way on an increase in demand of product, or other factors, which are reasonably attributed in a distinct manner to other e-KPIs.

Every improvement program has a cost, which is why we ask: how many e-KPIs, for which performance has been proved unsatisfactory, can be considered part of a program to improve energy-related performances? For example, the decision on whether to consider the analysis of a single indicator with the lowest value, or the first two indicators with the lowest values among those that makes up the Lean Energy Indicator.

In this regard, a Pareto analysis applied to the individual energy consumption that composes the eKPI is deemed extremely useful in order to optimize energy consumption and costs. Nevertheless, since the Pareto chart compares individual causes (e-KPI or individual energy consumption) of the total consumption of the period, this instrument should only be used for analysis of the current period, and cannot be used to evaluate an increase or a reduction of individual contribution in time. Finally, one may wonder what kind of improvement one can expect from a method that enables continuous improvement through the modes which are just explicated. At this point, the proposed eKPI method enables both direct and indirect improvements:

- direct improvements on energy-related performances closely related to energy consumption, such as thermodynamic KPIs (total energy consumption of the plant) or physicalthermodynamic KPIs (e.g. SEC ), etc.;

- indirect impact on time-based performances since the supporting mechanisms which aim at improving energy efficiency might also improve the time effectiveness of a manufacturing system. Notwithstanding, it is necessary to take into account that the improvements are made for this level of analysis in relation to problems of a single resource, but instead one must consider that the sum of local optima is not equal to a global optimum;

- the indirect improvements on energy-related performances that includes, in addition to energy consumption, other variables (e.g. economic and physical KPIs). Despite the improvement in energy consumption, high energy prices that outweigh the achieved improvement nullify the effect of the proposed action plan;

- the indirect improvement, more globally, on sustainable manufacturing. 


\section{Discussion and Concluding Remarks}

The e-KPIs enable improved energy-related performances. The clustering of the manufacturing states are carried out to foster a continuous improvement loop as the e-KPIs identify weaknesses and areas for energy efficiency improvements related to the management of production and operations. Thus, an action plan tasked with achieving energy-saving targets is created for relevant actors within an organization.

One limitation of the developed method is the availability of energy-related data. Even if a precise calculation of all indicators is performed, problems may occur due to granularity of available data. In the current situation, energy monitoring is widely done on factory level, but to really use the approach, a finer granularity on machine level is necessary. Widely, the infrastructure for this approach might yet be missing in industry, especially in Small and Medium-sized Enterprises (SMEs). A real and complete case analysis can only be done in a time frame in which the multilevel energy measurement and monitoring systems allow energy analysis for different levels of the plant, down to machine level.

However, such limitation could be dealt with by increasing the role and use of advanced IT systems in manufacturing environments (May et al. 2013c). For instance, addressing the challenge highlighted in the Figure 7 below by May et al. (2012), PLANTCockpit (PLANTCockpit, 2014) developed a central monitoring system which is able to access different data sources (e.g. ERP, MES, SCADA, Energy Apps, other special-purpose solutions, etc.) in a manufacturing facility in order to integrate, process and visualize production data, thus enabling consistent calculation and visualization of desired indicators such as e-KPIs developed in this study.

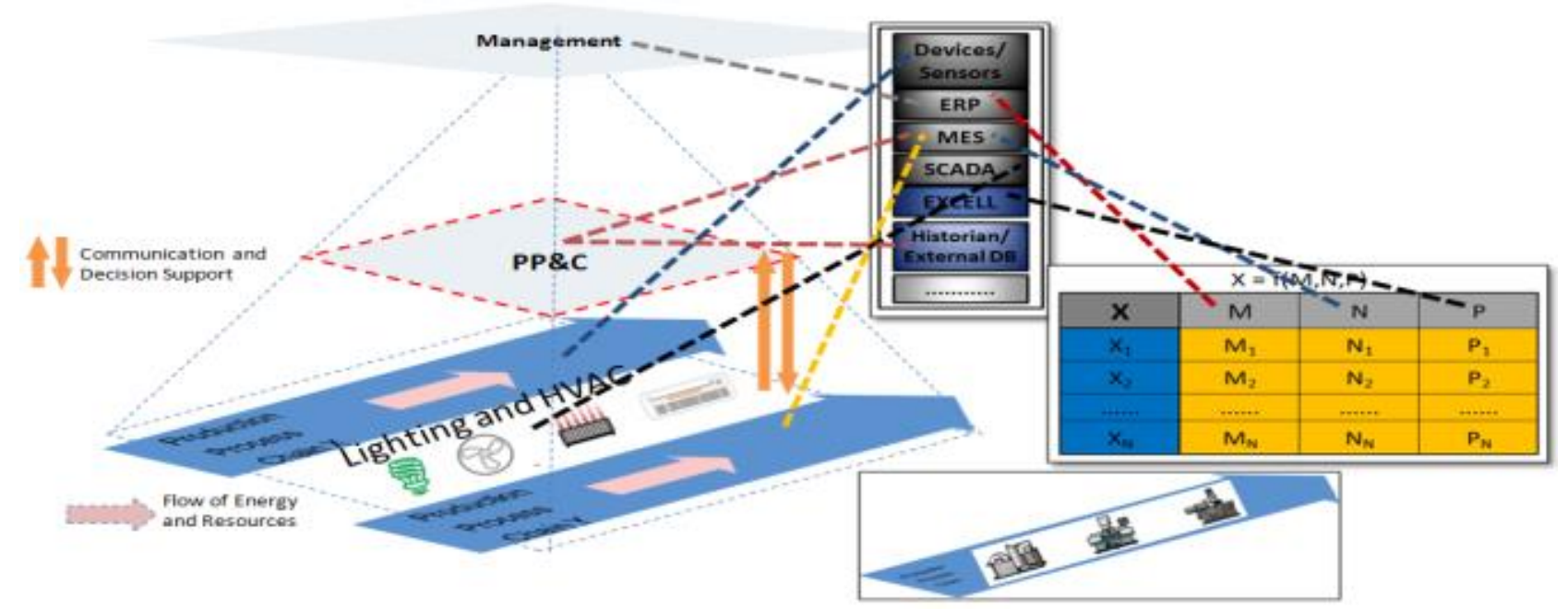

Figure 7. Sample data sources and KPI components in a manufacturing plant (May et al., 2012) 
Although it is difficult to directly measure the data required for calculating these e-KPIs in the current settings, it is possible to reach the data components of each indicator with the use of new generation IT systems such as PLANTCockpit or else, which will lead the industry to be able to frequently calculate and visualize the desired indicators such as e-KPIs.

We proceed now to illustrate a number of key points and findings relating to the proposed method. The developed method is proposed to address the research gaps identified in the literature review. It aims to support the manufacturing industry in fulfilling the identified industrial needs. Since it contributes to a research topic focused on a medium to long term trend and as the contribution is made by developing new KPIs to support energy management, technical and economic evaluations for the implementation of the method are considered out of scope. The discussion of implementation hints in section 4.7.2. is provided for the sole purpose of outlining a possible estimate of the time horizon over which the manufacturers could be able to use the designed e-KPIs in a structured way.

During the development of the method, the following important findings emerged:

- The reference system in which a production machine works strongly influences its energyrelated performances.

- The presence of a high number of intervention mechanisms related to the manufacturing states confirms the wide possibilities of reducing energy consumption by acting on production system (or on such variables) rather than on technological levers.

- The development of e-KPIs through appropriate Energy Diagram allows the KPI values not to be affected by changes in market demand, except by a change in the product mix, for which there might be an incidence of setup.

- Not all of the energy inefficiencies are equally important and potential hotspots in terms of energy management: the energy consumption matrix is designed including time and power dimensions and shows the types of energy consumption on which to pay more attention for improving the energy-related performances.

- The development of the e-KPIs showed that there were negligible time-based performance indicators which instead have strong impacts on energy-based performance. Such states are positioned on the lower right of the energy consumption matrix: the most representative example is the state that corresponds to machine start-up, both due to the needs of shifts and to total failure. The occurrence of these states must be avoided as much as possible since these small time intervals could have high impacts on energy consumption. 
Ultimately, we describe as follows opportunities for future development which could further deepen the knowledge of the study:

- The developed tools can be used more widespread for other means. For example, modelling by state graph can be used to support discrete event simulation in order to study the energy behavior of the resource at different scenarios and to predict energy consumption for instance by providing relevant information concerning the best choice of the supply contract or ideal shifts for the plant, etc.

- Other tools might be used for representing the cause-effect relationships, e.g. causal loop diagrams. They allow connecting the related elements by cause-effect links, determining the signs and possible loop between the different links, and designing equations for each link.

- One other way is to consider other possibilities for development of methodologies aimed at improving energy efficiency. One such method might consider development of e-KPIs on different levels (i.e. machine, process, and plant level), and relationships in-between these KPIs. Another method could consider effects of different instruments on energy consumption, e.g. contribution of different plans (e.g. inventory management, capacity planning, etc.) on the energy performance of the plant or the entire supply chain can be studied, using simulation environments supported by key performance indicators for the evaluation of different scenarios.

- Last but not least, e-KPIs could be used in simulation environments to evaluate the effectiveness of actions over time. It could also be aimed at achieving improvements of energy performances at machine level. However, since production systems represent extremely complex environments in which a global optimum is not the sum of local optima, the scope of the discussion should be reasonably extended to a line, to a plant, to a portion of the supply chain, etc. in order to formulate a comprehensive solution considering the entire value chain. 


\section{Appendix A}

We introduce below the symbols used in the formulas for calculating indicators in Section 4.6.:

- $\quad \mathrm{i}$ : index of the piece in the product mix

- $n$ : number of pieces in the product mix

- $Q_{\text {good } i}$ : Quantity of saleable pieces

- Qrew: Quantity reworked

- $\quad \mathrm{q}_{\mathrm{r}}$ : Quantity discarded

- $\quad \mathrm{q}_{\mathrm{rs}}$ : Quantity discarded in startup

- $\quad T_{\text {processing } i}:$ Processing time

- $\quad P_{\text {processing } i}:$ Average processing power

- NCTi: Number of tool change for each piece "i"

- $\quad \mathrm{T}_{\mathrm{su}}$ : Setup time

- $\mathrm{P}_{\text {setup: }}$ Average power consumption for tool change

- $\quad \mathrm{T}_{\text {micro: }}$ Total Time lost due to machine microstoppages

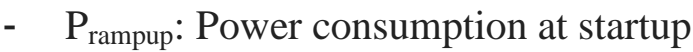

- $\quad \mathrm{T}_{\text {rampup: Time to start the machine }}$

- $\quad \mathrm{NS}_{\mathrm{pf}}$ : Number of starts after failure

- $\quad \mathrm{T}_{\mathrm{TRp}}$ : Repair Time of preventive interventions (assumes only adjustments)

- $\mathrm{P}_{\text {Maint }}$ : Power consumption during maintenance

- $\mathrm{T}_{\text {maint: }}$ Maintenance time

- $\mathrm{T}_{\text {down }}$ : Downtime

- $\quad P_{\text {idle: Power consumption at idle }}$

- $\quad \mathrm{T}_{\mathrm{w}}$ : Total Time for workers' stoppages

- $\quad T_{\text {bsps: }}$ Time lost due to blocking \& starvation for production scheduling

- $\mathrm{T}_{\mathrm{wttm}}$ : Waiting time for tool management

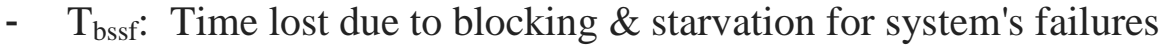

- $\quad \mathrm{T}_{\mathrm{wtbr}}$ : Waiting time for breakdown or regeneration

- $\mathrm{P}_{\text {standby }}$ : Power consumption in standby

- $\quad \mathrm{T}_{\mathrm{mo}}$ : Time lost due to missing orders

- $\quad \mathrm{T}_{\mathrm{mm}}$ : Time lost due to missing materials

- $\quad \mathrm{Ns}_{\mathrm{t}}$ : Number of starts by shifts

- $\quad \mathrm{NS}_{\mathrm{PH}}$ : Number of starts after holidays 


\section{References}

Aguirre, F., Villalobos J.R., Phelan, P.E., Pacheco, R., 2011. Assessing the relative efficiency of energy use among similar manufacturing industries. International Journal of Energy Research 35(6): 477-488.

Ang B.W., 2006. Monitoring changes in economy-wide energy efficiency: from energy-GDP ratio to composite efficiency index. Energy Policy 34:574-582.

Aramcharoen, A., Mativenga, P.T., 2014. Critical factors in energy demand modelling for CNC milling and impact of toolpath strategy. Journal of Cleaner Production (2014), http://dx.doi.org/10.1016/j.jclepro.2014.04.065

Boyd, G., Dutrow, E., Tunnessen, W., 2008. The evolution of the "energy star" energy performance indicator for benchmarking industrial plant manufacturing energy use. Journal of Cleaner Production 16(6): 709-715.

Bunse, K., Vodicka, M., Schönsleben, P., Brülhart, M., Ernst, F.O., 2011. Integrating energy efficiency performance in production management - gap analysis between industrial needs and scientific literature. Journal of Cleaner Production 19(6-7): 667-679.

Cagno, E., Trianni, A., 2013. Exploring drivers for energy efficiency within small- and mediumsized enterprises: First evidences from Italian manufacturing enterprises. Applied Energy 104: 276285.

Calvanese, M.L., Albertelli, P., Matta, A., Taisch, M., 2013. Analysis of Energy Consumption in CNC Machining Centers and Determination of Optimal Cutting Conditions. In: Proceedings of 20th CIRP International Conference on Life Cycle Engineering, Singapore.

Cannata, A., Taisch, M., Vallo, E., 2010. Energy Efficiency Optimization through Production Management Decisions in Manufacturing Environment: A Proposal. In: Proceedings of International Conference on Advances in Production Management Systems, Como, Italy.

Cruycke, B., 2008. Energy monitoring - A must for textile companies. Melliand International 14(5): 324-325.

Devoldere, T., Dewulf, W., Deprez, W., Willems, B., Duflou, J. R., 2007. Improvement potential for energy consumption in discrete part production machines. In: Proceedings of the 14th CIRP Conference on Life Cycle Engineering, 311-316

Dietmair, A., Verl, A., 2009. A generic energy consumption model for decision making and energy efficiency optimisation in manufacturing, International Journal of Manufacturing Research 2(2): $123-133$.

Dietmair, A., Verl, A., Eberspaecher, P., 2011. Model based energy consumption optimisation in manufacturing system and machine control. International Journal of Manufacturing Research 6(4): 380-401.

Dobes, V., 2013. New tool for promotion of energy management and cleaner production on no cure, no pay basis. Journal of Cleaner Production 39: 255-264.

Drake, D.F. and Spinler, S., 2013. Sustainable Operations Management: An enduring stream of passing fancy? Manufacturing and Service Operations Management 15(4): 689-700.European Commission, 2010. EUROPE 2020 A strategy for smart, sustainable and inclusive growth. http://ec.europa.eu/europe2020/index_en.htm. 
European Environment Agency, 2010. The European Environment State and Outlook 2010, Available at: http://www.eea.europa.eu/soer.

Feng, S. C., Joung, C. B., 2009. An overview of a proposed measurement infrastructure for sustainable manufacturing. In Proceedings of the 7th Global Conference on Sustainable Manufacturing.

Friedler, F., 2010. Process integration, modelling and optimisation for energy saving and pollution reduction. Applied Thermal Engineering 30: 2270-2280.

Garetti, M., Taisch, M., 2012. Sustainable manufacturing: trends and research challenges. Production Planning \& Control 23(2-3): 83-104.

Giacone, E., Mancò, S., 2012. Energy efficiency measurement in industrial processes. Journal of Energy 38(1): 331-345.

Giacone, E., Mancò, S., Gabriele, P., 2008. Energy management techniques for small- and mediumsized companies. Journal of Energy Resources Technology 130(1): 120021-120027.

Grando A., Turco F., 2005. Plant Capacity and Productivity Measurement. Conceptual framework and a single-machine case. Production Planning and Control 16(3): 309-322.

Gutowski, T., Dahmus, J., Thiriez, A., 2006. Electrical Energy Requirements for Manufacturing Processes. In: Proceedings of the 13th CIRP International Conference on Life Cycle Engineering, 623-627.

He, Y., Liu, F., Wu, T., Zhong, F.-P., Peng, B., 2012. Analysis and estimation of energy consumption for numerical control machining. Journal of Engineering Manufacture 226(2): 255266.

Hon., K. K. B., 2005. Performance and evaluation of manufacturing systems. CIRP Annals Manufacturing Technology 54(2): 139-154.

Honma, S., Hu, J., 2014. Industry-level total-factor energy efficiency in developed countries: A Japan-centered analysis. Applied Energy 119: 67-78.

Hu, S., Liu, F., He, Y., Hu, T., 2012. An on-line approach for energy efficiency monitoring of machine tools. Journal of Cleaner Production 27: 133-140.

Huang, T., 2008. Strategies for energy reduction in semiconductor manufacturing. Solid State Technology 51: 30-35.

International Energy Agency (IEA), 2013. International Energy Outlook 2013, available at: http://www.eia.gov/forecasts/ieo/pdf/0484(2013).pdf

Karali, N., Xu, T., Sathaye, J., 2014. Reducing energy consumption and CO2 emissions by energy efficiency measures and international trading: A bottom-up modeling for the U.S. iron and steel sector. Applied Energy 120: 133-146.

Kissock, J.K., Eger, C., 2008. Measuring industrial energy savings. Applied Energy 85: 347-361.

Kong, L., Price, L., Hasanbeigi, A., Liu, H., Li, J., 2013. Potential for reducing paper mill energy use and carbon dioxide emissions through plant-wide energy audits: A case study in China. Applied Energy 102: 1334-1342.

May, G., Taisch, M., Geoghegan, K., Beccaris, M., 2012. Improving Energy Efficiency in Manufacturing via KPI Intelligence Based on Plant Integration. Proceedings of the 10th Global Conference on Sustainable Manufacturing. Istanbul, Turkey. 
May, G., Taisch, M., Prabhu, V., Barletta, I., 2013a. Energy related key performance indicators state of the art, gaps and industrial needs. Advances in Production Management Systems. Sustainable Production and Service Supply Chains. IFIP Advances in Information and Communication Technology 414 (1): 257-267.

May, G., Taisch, M., Stahl, B., Sadr, V., 2013b. Toward Energy Efficient Manufacturing: A Study on Practices and Viewpoint of the Industry. Advances in Production Management Systems. Competitive Manufacturing for Innovative Products and Services. IFIP Advances in Information and Communication Technology 397 (1): 1-8.

May, G., Taisch, M., Kelly, D., 2013c. Enhanced energy management in manufacturing through systems integration. IECON 2013 - 39th Annual Conference of the IEEE Industrial Electronics Society. Available at: http://dx.doi.org/10.1109/iecon.2013.6700386.

Meredith, J., 1993: Theory building through conceptual models. International Journal of Operations \& Production Management 13(5): 3-11.

Moreno, B., Garcia-Alvarez, M.T., Ramos, C., Fernandez-Vazquez, E., 2014. A General Maximum Entropy Econometric approach to model industrial electricity prices in Spain: A challenge for the competitiveness. Applied Energy 135: 815-824.

Morvay, Z. K, Gvozdenac, D. D., 2008. Applied industrial energy and environmental management. Chichester, West Sussex, U.K.: Wiley .

Mouzon, G., Yildirim, M. B., Twomey, J., 2007. Operational methods for minimization of energy consumption of manufacturing equipment. International Journal of Production Research 45 (18-19): 4247-4271.

Palm, J., Thollander, P., 2010. An interdisciplinary perspective on industrial energy efficiency. Applied Energy 87: 3255-3261.

PLANTCockpit EU-funded Project, 2014. Available at: www.plantcockpit.eu [accessed on 29.10.2014].

Rudberg, M., Waldemarsson, M., Lidestam, H., 2013. Strategic perspectives on energy management: A case study in the process industry. Applied Energy 104: 487-496.

Saidur, R., Mekhile, S., 2010. Energy use, energy savings and emission analysis in the Malaysian rubber producing industries. Applied Energy 87: 2746-2758.

Shi, X., 2014. Setting effective mandatory energy efficiency standards and labelling regulations: A review of best practices in the Asia Pacific region. Applied Energy 133: 135-143.

Song, C., Li, M., Wen, Z., He, Y., Tao, W., Li, Y., Wei, X., Yin, X., Huang, X., 2014. Research on energy efficiency evaluation based on indicators for industry sectors in China. Applied Energy 134: $550-562$.

Soundararajan, K., Ho, H.K., Su, B., 2014. Sankey diagram framework for energy and exergy flows. Applied Energy (2014). http://dx.doi.org/10.1016/j.apenergy.2014.08.070

Sun, Z., Biller, S., Gu, F., Li, L., 2011. Energy consumption reduction for sustainable manufacturing systems considering machines with multiple power states. In: Proceedings of the International Manufacturing, Science and Engineering Conference, 99-103.

Tanaka, K., 2008. Assessment of energy efficiency performance measures in industry and their application for policy. Energy Policy 36: 2887-2902. 
Thollander, P., Backlund, S., Trianni, A., Cagno, E., 2013. Beyond barriers - A case study on driving forces for improved energy efficiency in the foundry industries in Finland, France, Germany, Italy, Poland, Spain, and Sweden. Applied Energy 111: 636-643.

Thollander, P., Karlsson, M., Söderström, M., Creutz, D., 2005. Reducing industrial energy costs through energy-efficiency measures in a liberalized European electricity market: case study of a Swedish iron foundry. Applied Energy 81: 115-126.

Trianni, A., Cagno, E., Donatis, A., 2014. A framework to characterize energy efficiency measures. Applied Energy 118: 207-220.

Tucker, R., Ward, J., 2012. Identifying and quantifying energy savings on fired plant using low cost modelling techniques. Applied Energy 89: 127-132.

US EPA, 2003. ENERGY STAR - the power to protect the environment through energy efficiency. Washington, DC: US Environmental Protection Agency.

Vikhorev, K., Greenough, R., Brown N., 2013. An advanced energy management framework to promote energy awareness. Journal of Cleaner Production 43: 103-112.

Wang, Z., Zeng, H., Wei, Y., Zhang, Y., 2012. Regional total factor energy efficiency: An empirical analysis of industrial sector in China. Applied Energy 97: 115-123.

Wang, S., Fang, C., Guan, X., Pang, B., Ma, H., 2014. Urbanisation, energy consumption, and carbon dioxide emissions in China: A panel data analysis of China's provinces. Applied Energy 136: $738-749$.

$\mathrm{Xu}$, T., Karali, N., Sathaye, J., 2014. Undertaking high impact strategies: The role of national efficiency measures in long-term energy and emission reduction in steel making. Applied Energy 122: $179-188$.

Xu, X., Zhao, T., Liu, N., Kang, J., 2014. Changes of energy-related GHG emissions in China: An empirical analysis from sectoral perspective. Applied Energy 132: 298-307.

Zhou, P., Ang, B.W., Zhou, D.Q., 2012. Measuring economy-wide energy efficiency performance: a parametric frontier approach. Applied Energy 90: 196-200.

Zhu, Q., et al., 2014. Production energy optimization using low dynamic programming, a decision support tool for sustainable manufacturing, Journal of Cleaner Production (2014), http://dx.doi.org/10.1016/j.jclepro.2014.02.066 